\title{
Universiteit
}

Leiden

The Netherlands

\section{Illustrated incunabula as material objects: the case of the devout hours on the life and passion of Jesus}

Christ

Dlabacova, A.; Hofman, R.H.F.; Caspers, C.M.A.; Nissen, P.; Dijk, M. van; Oosterman, J.

\section{Citation}

Dlabacova, A. (2020). Illustrated incunabula as material objects: the case of the devout hours on the life and passion of Jesus Christ. In R. H. F. Hofman, C. M. A. Caspers, P. Nissen, M. van Dijk, \& J.

Oosterman (Eds.), Medieval Church Studies (pp. 181-221). Turnhout: Brepols. doi:10.1484/M.MCS-EB.5.119395

Version:

Publisher's Version

License: Licensed under Article 25fa Copyright Act/Law (Amendment Taverne)

Downloaded from: $\quad$ https://hdl.handle.net/1887/3220736

Note: To cite this publication please use the final published version (if applicable). 


\title{
ILLUSTRATED INCUNABULA AS MATERIAL OBJECTS: THE CASE OF THE DEVOUT HOURS ON THE LIFE AND PASSION OF JESUS CHRIST
}

\author{
Anna Dlabačová*
}

I

$\mathrm{n}$ the age of transition from manuscript to print, texts and images circulated in both media and there is ample evidence of cross-fertilization. ${ }^{1}$ The Devout Hours on the Life and Passion of Jesus Christ (Devote ghetiden vanden leven ende passie Jesu Christi) are a telling example of a religious text-and-image-

* The research for this publication has been carried out as part of the projects 'Text and Image on the Printing Press: The Complementarity of the Textual and the Visual in Antwerp's Book Production, 1480-1520' (Marie-Curie Co-fund, Université catholique de Louvain, 2015-2017) and 'Leaving a Lasting Impression. The Impact of Incunabula on Late Medieval Spirituality, Religious Practice and Visual Culture in the Low Countries' (NWO-Veni, 2018-2022). I am grateful to the editor of the present volume, Rijcklof Hofman, for his remarks and suggestions which greatly improved the text.

${ }^{1}$ See especially McKitterick, Print, Manuscript, and the Search for Order, and the older work by Sandra Hindman, e.g. Hindman, Pen to Press. In the notes below, the following abbreviations are used: ISTC (Incunabula Short Title Catalogue, British Library: www,bl.uk/catalogues/istc/ index.html) and ILC (Van Thienen and Goldfinch, Incunabula Printed in the Low Countries).

\footnotetext{
Anna Dlabačová (a.dlabacova@hum.leidenuniv.nl) is Assistant Professor and postdoctoral researcher at Leiden University. She is preparing a monograph on the religious editions published by the printer Gerard Leeu within her NWO (Netherlands Organization for Scientific Research) Veni-project 'Leaving a Lasting Impression. The Impact of Incunabula on Late Medieval Spirituality, Religious Practice and Visual Culture in the Low Countries'. Before that, she conducted a project on text and image on the early printing press at the Université catholique de Louvain.
}

Inwardness, Individualization, and Religious Agency in the Late Medieval Low Countries, ed. by Rijcklof Hofman, Charles Caspers, Peter Nissen, Mathilde van Dijk, and Johan Oosterman, MCS 43 (Turnhout: Brepols, 2020), pp. 181-221 
complex expressly directed at lay readers. The text and images were transmitted in printed editions using woodcuts for illustration and - in varying constellations - in richly decorated manuscripts with painted miniatures and borders, in plainer manuscripts with washed pen-drawings, in a 'hybrid book' that combines engravings with handwritten text, but also in simple manuscripts without any form of illustration at all. ${ }^{2}$

Even though in the latter half of the fifteenth century manuscripts offered most possibilities for the individualization of text and image - keeping in mind that the production of manuscripts and especially books of hours was increasingly large-scale and commercialized - , it is well known that a (cheaper) copy of a printed illustrated book also presented its purchaser with several options to make the book his/her own. ${ }^{3}$ The sheets with text and images printed in black ink were sent into a still largely 'handwritten world', dominated by the age-old manuscript culture. Here, the 'naked copy' encountered owners and readers with various interests, preferences, and budgets. Individual copies of incunabula were embellished, used, appropriated, modified, and therefore personalized and individualized. As such, their materiality provides important clues about the dissemination of texts and images, about their reception and consumption, and about personal preferences that shaped the customization of a ready made book. Art historians Graham Larkin and Lisa Pon have already argued the importance of the materiality of printed words and images. ${ }^{4}$

The aim of this essay is to test a holistic approach to illustrated religious incunabula as material objects that reflect the interplay between religious developments, book printing, and the devotional practices of their late medieval - in this case lay - users. In doing so, I aim to provide a 'template' for the types of evidence and the way they can be interpreted in connection to each other and to the (presentation of the) text.

Printed in five editions over the course of the 1480s and 1490s, of which currently a total of seven copies are known (see Table 5), the Devout Hours offer a relatively small corpus that allows for a close scrutiny of material aspects and a treatment of the copies 'as if they were manuscripts'. The fact that only one of the copies contains a still decipherable inscription by its late medieval owner adds to the interest of this particular case study. Owners' inscriptions are relatively scarce

2 Dlabačová, 'Religious Practice and Experimental Book Production'.

${ }^{3}$ With regard to Leeu's books Goudriaan and Willems, Gheraert Leeu, p. 13, speak of 'semifinished products' ('halffabrikaat').

${ }^{4}$ See the special issue of Word \& Image and in particular Larkin and Pon, 'Introduction' and Chartier, 'Afterword: Materiality and Meaning. Cf. Parshall, 'Prints as Objects of Consumption'. 
in this kind of small, religious book..$^{5}$ Is it possible to distil data about the use of illustrated incunabula from 'circumstantial' material evidence only?

In what follows I will first briefly introduce the text and its presentation in the book as it would have come from the printing press. The major part of this essay is dedicated to a discussion of individual copies and as such to an exploration of how copies of illustrated incunabula can be approached as material artefacts.

Table 5. Extant copies of the Devout Hours on the Life and Passion of Jesus Christ.

\begin{tabular}{ll}
\hline Editions Copies \\
\hline
\end{tabular}

Gerard Leeu, [Gouda, 1483, before 10

December], $8^{\circ}$.

San Marino, CA, Huntington Library, 100989

ILC 1245; ISTC ih00433130.

(wanting leaves 1, blank, and 8)

Antwerpen, Ruusbroecgenootschap, L.P. 20/ m1099E4 (wanting leaves 16, 24, 58, 63, 64, 84, $85,121-128,149$, and 150)

Gerard Leeu, [Antwerpen, between 18 Leiden, Universiteitsbibliotheek, 1498 F 1 September 1484 and 9 July 1485 ], $8^{\circ}$. (wanting leaf $\mathrm{t} 8$ )

ILC 1246; ISTC ih00433150.

Jacob Bellaert, [Haarlem, 8 April-20 August

Amsterdam, Universiteitsbibliotheek, Inc. 421

1486], $8^{\circ}$.

(wanting leaves a1-2, a7-8, b1, b8, t8)

ILC 1431; ISTC il00186500.

Claes Leeu, Antwerpen, 29 November 1487, $8^{\circ}$. London, British Library, IA.49933 (wanting ILC 1247; ISTC ih00433200. leaves b5; c6; e2, e4, e5, e6, e8; h4; i8; m7, m8; n $1-8 ; \mathrm{p} 6, \mathrm{p} 7 ; \mathrm{r} 5-8 ; \mathrm{s} 1-4 ; \mathrm{t} 1, \mathrm{t} 4-5)$

Collaciebroeders, Gouda, 3 October 1496, $8^{\circ}$. ILC 1248; ISTC ih00433250.

Cambridge, University Library, Inc.5.E.3.10[2890] (wanting leaves n. 3-6)

Den Haag, Koninklijke Bibliotheek, 150 E 3 (wanting leaves 1, a3-b1, b6-c5, e3-6, h7-8, n1, p8 and s8)

${ }^{5}$ In folio editions such as the Boeck van den leven Jhesu Christi (Book on the Life of Christ), a dialogic text based on Ludolf of Saxony's Vita Christi, owners' inscriptions seem to be more frequent, see Dlabačová, 'Drukken en publieksgroepen', esp. pp. 341-46. 


\section{The Book of Hours Reinvented}

With the Devout Hours, Gerard Leeu (d. 1492), the Low Countries' most prolific and influential printer of the incunabula period (until 1501), created an innovative and commercially successful product. ${ }^{6}$ Right from the start, vernacular religious texts were a vital component of Leeu's business. He started his career in Gouda in the spring of 1477 by printing an edition of the Epistles and Gospels in Dutch. ${ }^{7}$ His Booklet on the office or service of the Mass (Boecxken van der officien ofte dienst der missen), which he published in 1479 in Gouda, became the first ever text (in 1481) to be printed in Antwerp. ${ }^{8}$ Three years later, in 1484, Leeu himself moved to the city on the Scheldt where he settled next to the city's art market and became the first printer to join the artists' guild of St Luke (in 1485-1486). ' Leeu was an important actor in Antwerp's development into the Netherlands' capital of printing in the sixteenth century. ${ }^{10}$ Many of the religious texts of which Leeu published the editio princeps became relatively successful, if not bestsellers reprinted in numerous editions well into the sixteenth century and sometimes even later, often with the use of Leeu's original woodblocks. ${ }^{11}$ Apart from his ability to read the market, Leeu must have maintained an impressive intellectual and creative network that provided guidance and assistance in acquiring copy and illustrational material. Most of his religious editions in the vernacular do not mention the author and/or editor and their relation to Leeu. The edition of the The Sinner's Consolation (Der zondaren troost) gives a rare indication concerning the acquisition of religious

${ }^{6}$ On Leeu see the volume edited by Goudriaan, Een drukker zoekt publiek. See also Goudriaan and Willems, Gheraert Leeu; Hellinga, 'Gheraert Leeu, Claes Leeu, Jacob Bellaert, Peter van Os van Breda'.

${ }^{7}$ Epistolae et Evangelia [Dutch], [Gouda: Gerard Leeu], 24 May 1477 (ILC 942; ISTC ie00064700).

${ }^{8}$ Leeu published the text on 20 July 1479 in Gouda (ILC 1986; ISTC is00529000). The text was reprinted by Mathias van der Goes in Antwerp on 8 June 1481 (ILC 1987; ISTC is 00529100). This is the first known book printed in Antwerp. Cf. for example Renaud, 'The emergence of Antwerp as a printing centre', p. 12. Analysis of the text and facsimile edition in Van Venlo, Boexken van der officien.

${ }^{9}$ Van der Stock, Printing Images in Antwerp, pp. 27-30.

${ }^{10}$ Cf. Goudriaan and Willems, Gheraert Leeu, p. 20.

${ }^{11}$ Examples include the Boeck vanden leven Jhesu Christi (first edition ILC 1503; ISTC il00353000) and Liden ende die passie Ons Heeren Jesu Christi (first edition ILC 1447; ISTC il00212900). On the latter text, see Van Moolenbroek, “'Dat liden”'. On the Boeck see Dlabačová, 'Chatten met Scriptura'. 
texts. The colophon states that the author, Johannes de Reimerswaal, a friar of the Antwerp Franciscan House that adhered to the Observance, finished writing the text on 20 March 1492 and that Leeu printed the book that same week. ${ }^{12}$ Apparently, the text was written expressly for the press with Leeu's knowledge. Once the text was finished, he secured a swift publication.

There are no concrete data about how Leeu acquired the Devout Hours, however. The voice of the author-compiler who wrote new and collected existing texts - whether or not with the intention of publishing the book with Leeu can be heard most clearly in the prologue, in which he explains waer om dattet ghemaect is, hoe dattet gheoerdineert is, ende waer toe dattet profitelick is (why it [the text/book] is made, how it is structured, and why it is profitable). ${ }^{13}$ For the sake of lay people who do not have the time to pray the para-liturgical hours contained in a book of hours, the author-compiler has collected seven short 'hours', penitential psalms, and prayers for each day of the week. ${ }^{14}$ The existing book of hours was no longer deemed adequate as a devotional instrument. Lay people required a weekly exercise that was more closely tailored to their needs and the author-compiler sought to satisfy this need. Because of his fairly elaborate description of the priesthood as the exemplary way of life on earth next to the contemplative life symbolised by Martha's sister Mary (Luke 10:42) on which he spends one sentence only —, Léonce Reypens has suggested that the author-compiler was a priest. ${ }^{15}$ The latter's insight into 'what lay people want' certainly points to an active involvement in pastoral care. Was the authorcompiler a member of the secular clergy in Gouda or an inhabitant of one of the town's religious communities, for example the Franciscan Observant friary or the Collaciebroeders (a local variant of the Brothers of the Common Life)? ${ }^{16}$

However this may be, the exercise, printed on nineteen quires of eight folia, amounting to a total number of 152 leaves, in small octavo format convenient for private study and meditation offers the reader a well thought-out and richly illustrated programme of spiritual growth. One of Leeu's first and most significant and influential series of religious woodcuts fits only this text and was thus

12 ILC 1355; ISTC ij00399500. Dlabačová and Prochowski, 'Preken en publiceren', p. 225.

13 Reypens, 'Belang der “Devote ghetiden”, p. 411. 114-15.

${ }^{14}$ Reypens, 'Belang der “Devote ghetiden”', pp. 410-11. 111-17.

15 Reypens, 'Belang der “Devote ghetiden”', pp. 406-07.

16 The Franciscan friary in Gouda was the intellectual center of the Observant movement in the Low Countries, see Dlabačová, Literatuur en observantie, esp. pp. 39-42. The Collaciebroeders ran a printing press from the 1490s onward and also issued an edition of the Devote ghetiden. On their printing activity see Goudriaan, 'Apostolate and Printing'. 
— as a whole — made for this 'alternative layman's book of hours. ${ }^{17}$ In all further editions Leeu's series was reused except for the edition printed in Haarlem in 1486 by Jacob Bellaert. Despite of his close connections to Leeu, Bellaert had a new woodcut series made. ${ }^{18}$ Whether or not the illustrational programme was anticipated by the author-compiler and/or whether he was involved in the design of the book, remains an open question. Nevertheless, there is no doubt that the integration of a high number of images into the text - Leeu used no fewer than 68 woodblocks for the first edition - contributed to its success.

The books form a unity of text and image and their users were as much readers as they were viewers. Each chapter starts with a woodcut of, and a meditative exercise on, the subject matter of that day. The reader was to consider Death on Monday, the Last Judgement on Tuesday, and Hell on Wednesday. Thursday was reserved for the love and gifts of God and Friday for the Passion of Jesus Christ. On Saturday the reader focused on confession, followed by the last of the quattuor novissima, Heaven, on Sunday. These meditative texts are detailed descriptions in which each section is preceded by an imperative that prompts the reader to internalize the account: think, consider (dencket, overdencket, aendencket, overlegghet), notice (merket), take or have something in your thoughts (bebt in uwe ghedachten) or even to mentally examine (besiet ende ondersoect). ${ }^{19}$ The devotee's figurative meditation is further stimulated by commanding him/her to see ((aen) siet), to place something before the eyes or to cast the (inner) eyes onto something (stelt/settet voer u oghen, slaet uwe inwendighe oghen ende ghedachten $o p$ ), to contemplate or envisage something inwardly (beschouwet inwendelik), and - with regard to the Passion - to see both with the heart and the eyes (siet mit harten ende mit oghen). ${ }^{20}$ The meditative texts thus consist of prescriptive sequences of thoughts and visualizations that can be seen as emotional scripts. ${ }^{21}$

${ }^{17}$ Kok, Woodcuts in Incunabula, I, p. 172. Conway, The Woodcutters of the Netherlands, pp. 46-47. Rosier, 'Gheraert Leeus illustraties'. Dlabačová, 'Religious Practice and Experimental Book Production'.

${ }^{18}$ Kok, 'A Rediscovered Devote ghetiden', pp. 167-83; Kok, Woodcuts in Incunabula, I, p. 171. Dlabačová, 'Religious Practice and Experimental Book Production'.

19 Antwerpen, RG, L.P. 20/m1099E4. Examples include fol. a 8 v 'overdencket dat die ure des doots sekerlijck ende sonder twivel comen sal'; $b 1^{v}$ 'dencket nu dit'; fol. a $8^{\mathrm{r}}$ 'overlegghe huden in dese ghetide dat ghi cortelick van dit leven moet reysen'. Other examples on fols a $8^{\mathrm{v}}$ $\mathrm{b} 1^{\mathrm{r}}, \mathrm{b} 2^{\mathrm{v}}, \mathrm{d} 2^{\mathrm{v}}, \mathrm{h} 8^{\mathrm{v}}, \mathrm{i} 2^{\mathrm{v}}$.

${ }^{20}$ Antwerpen, RG, L.P. 20/m1099E4. An example is (fol. d2 $2^{\mathrm{r}}$ ' 'Slaet uwe inwendighe oghen ende ghedachten op dat uterste oerdel'. Other examples on fols $\mathrm{d} 3^{\mathrm{v}}, \mathrm{d} 5^{\mathrm{r}}, \mathrm{h} 8^{\mathrm{r}}, 15^{\mathrm{rv}}$.

21 The sequence for Wednesday $\left(\right.$ fols $\left.f 5^{\mathrm{r}}-8^{\mathrm{r}}\right)$ : Meert oeck u inwendighe oghe opten 
The images that precede each of these texts — apart from structuring the book serve as a starting point for the meditation.

The meditations are followed by one of the seven penitential psalms (in an 'extended' version that combines exegesis and meditation, probably an invention by the author-compiler), a prayer to the Trinity and a number of prayers on the history of salvation. ${ }^{22}$ In each chapter these prayers are followed by a short penitential psalm taken from the Psalter of Our Lady (Souter OLV). All texts except for the extended penitential psalms are accompanied by an image. In the prayer cycle on salvation history text and image take on a particularly close relationship as each opening presents the reader with an image and text diptych. ${ }^{23}$ Every day the reader should conclude his/her exercise by reciting the Adoro Te prayer in Middle Dutch and a prayer to All Saints. Their texts and the accompanying woodcut of the Mass of St Gregory are found only at the end of the chapter intended for Monday. From Tuesday onward a reference at the end of each chapter tells the reader to leaf backward in order to read these prayers (and to view the woodcut of St Gregory). ${ }^{24}$

Due to the nature of the text and the (intended) readership these books would have been kept in private possession and used in households or (lay) confraternities, which might also explain the low number of extant copies. ${ }^{25}$ But what can these few copies tell us about the Devout Hours as objects handled by reader-viewers and in turn about the impact these lavishly illustrated books had on late medieval spirituality?

helschen coninckrijc... Dencket dan ten eersten dat die helle is een gruwelike plaetse ... Siet alsulcke is dese plaets ... Dencket oeck op die veelheyt ende menigherhande pinen die daer sijn inder hellen ... Daer na soe overdencket oeck van die grootticheyt ende swaricheyt der pynen... Dencket in een ghelikenisse oft ghi in die winter alst zeer cout ware... Settet oeck voer u oghen ofte yemant liden mochte die pijn in enen heten barnenden oven... Daer na soe overlegghet wel ende dencket hoe dat die verdoemde vermaledide menschen pijn sullen liden... Dencket daer na op die wreetheyt der duvelen... Dencket oec op die inwendighe pinen... Overdencket dan ten lesten...'

22 This is also explained in his prologue: Reypens, 'Belang der "Devote ghetiden"', p. 411. $122-27$.

${ }^{23}$ Dlabačová, 'Religious Practice and Experimental Book Production'.

${ }^{24}$ Antwerpen, RG, L.P. 20/m1099E4, fol. f4r. On Saturday the Litany of Our Lady is added after the sixth Marian psalm. On Sunday the book concludes with prayers to the name of Jesus and the Virgin.

${ }^{25}$ Cf. Kok, Woodcuts in Incunabula, I, p. 172 and Dlabačová, 'Religious Practice and Experimental Book Production'. 


\section{Layers of Evidence}

The degree to which additions were made by hand differs from copy to copy and it is important to keep in mind that handmade finishes could be made and/or changed over time by several owners and/or craftsmen. One of the two copies of the first edition by Leeu and the only extant copy of his second edition represent the simplest form of handmade finishes: in these copies, rubrication (pilcrows, capital strokes, underlining) and initials have been added with red ink. ${ }^{26}$

The only extant copy of the fourth edition by Claes Leeu, Gerard's brother, also contains rubrication and initials, but here red ink has also been applied in varying gradations - to eight of the woodcuts. The red colour accentuates contours, details and emphasizes the focus on the central figure(s). ${ }^{27}$ Whether a more elaborate adornment of certain woodcuts happened on a random basis or whether the 'choice' of these images (Marriage of Mary and Joseph, Visitation, Christ disputing in the temple) can be seen as an indication of the interest of (a) reader(s) in particular events - and therefore as a kind of pictorial annotation - is thought-provoking, yet difficult to answer. Similarly, in many of the woodcuts in this copy yellow and brownish shades have been added, usually to items of clothing. ${ }^{28}$ Again, the colour, nowadays faded, appears to have added focus to the central figures, for example in the sequence of events from the agony in the garden of Gethsemane until Christ is brought before Herod, in which Christ's gown is consequently touched up. ${ }^{29}$ Sometimes the addition of yellow shade coincides with the treatment with red ink, as is the case in the Visitation (Plate I).

26 San Marino, CA, Huntington Libr., 100989 and Leiden, UB, 1498 F 1. The rubrication is executed in a consistent quality and was probably added by a professional craftsman. In the San Marino copy, which I have studied in digitized form only, rubrication is more elaborate (more pilcrows and underlining); compare for example fol. $\mathrm{c}^{\mathrm{v}}$. On fol. $\mathrm{cl}^{\mathrm{v}}$ of the Leiden copy a user tried to cover Eve's genitals with brown ink.

${ }^{27}$ London, BL, IA.49933. As several leaves are missing (see table above) the number of woodcuts with red accents might have been higher originally. Elaborate red accents have been added to fols $\mathrm{c}^{\mathrm{v}}$ (Marriage of Mary and St Joseph), e $3^{\mathrm{v}}$ (Visitation) and $\mathrm{f}^{\mathrm{v}}$ (Christ disputing in the temple). A limited number of red accents (mainly blood to wounds) can be found on fols $\mathrm{a} \mathrm{1}^{\mathrm{r}}$ (title page, Man of Sorrows), d1 ${ }^{\mathrm{v}}$ (Last Judgement), $\mathrm{e}^{\mathrm{v}}$ (Throne of grace), g $4^{\mathrm{v}}$ (Throne of grace), and $\mathrm{p} 4{ }^{\mathrm{v}}$ (Longinus piercing Christ's side). Pen flourishes have been added to two initials (fols a $2^{\mathrm{r}}$ and $\left.\mathrm{a} 8^{\mathrm{r}}\right)$.

${ }^{28}$ London, BL, IA.49933, fols e1 $1^{\mathrm{v}}, \mathrm{e}^{\mathrm{v}}$, e $7^{\mathrm{v}}, \mathrm{g} 4^{\mathrm{v}}, \mathrm{g} 6^{\mathrm{v}}, \mathrm{h} 3^{\mathrm{v}}, \mathrm{h} 4^{\mathrm{v}}, \mathrm{k} 1^{\mathrm{v}}-8^{\mathrm{v}}, 11^{\mathrm{v}}, 12^{\mathrm{v}}, 14^{\mathrm{v}}, \mathrm{o} 1^{\mathrm{v}}, \mathrm{o} 4^{\mathrm{v}}$, $\mathrm{p} 2^{\mathrm{v}}-5^{\mathrm{v}}, \mathrm{p} 8^{\mathrm{v}}$.

${ }^{29}$ London, BL, IA.49933, fols k $3^{\mathrm{v}}-12^{\mathrm{v}}$. 
Throughout the copy yellow colour has also been added in a fairly crude fashion over the impressions of the woodcut of Mary and the Christ Child clothed with the sun that accompany the short penitential psalms taken from the Psalter of Our Lady..$^{30}$ The added colour, although unassuming, does make Mary into an illuminated presence. Mary's face and the Child have been left uncoloured, drawing the eye of the reader-viewer effectively toward their intimate embrace. Furthermore, two of these pages are marked with (remnants of) clavicula (bookmarks). ${ }^{31}$ Together, colour and clavicula suggest a particular interest of the reader(s) in these psalms (Fig. 4). Possibly the copy's user(s) read only these short psalms every day of the week. A particular focus on Mary in the devotion of the reader(s) is confirmed by the additions made to the woodcut and very last prayer in the book, a Middle Dutch translation of Ave Maria, ancilla sanctae Trinitatis ascribed to St Bernard..$^{32}$ The woodcut, showing an image almost identical to the block that accompanies the Marian psalms, is embellished with yellow colour and a red ink that has oxidized and is thus different from the ink used in the other woodcuts. The same ink was used to add a reference to the Hail Mary (Ave Maria) after each verse of the prayer.

At the beginning of this copy, the reader is moreover confronted with two extra quires that contain handwritten prayers of which the lion's share is directed at Mary. ${ }^{33}$ The first quire also contains communion prayers and the second quire concludes with a prayer to St Peter. The prayers were written by six different

${ }^{30}$ London, BL, IA.49933, fols c5 $5^{\mathrm{v}}$, f. $3^{\mathrm{v}}, \mathrm{h} 6^{\mathrm{v}}, 13^{\mathrm{v}}$, o $3^{\mathrm{v}}, \mathrm{q} 1^{\mathrm{v}}$.

31 London, BL, IA.49933, fols f3 and 13.

32 London, BL, IA.49933, fols $\mathrm{t}^{\mathrm{v}}-8^{\mathrm{r}}$.

${ }^{33}$ London, BL, IA.49933. Bound in contemporary brown leather blind-tooled binding on wooden boards with a maculature taken from a twelfth-century liturgical manuscript. I would like to thank Erik Kwakkel (Leiden University) for dating the writing to 1150-1200 (e-mail dd. 5 April 2017). The two quires both count six leaves, not foliated: fols [ $\left.1^{\mathrm{r}}-1^{\mathrm{v}}\right]$ : 'dyt gebet lerde onse lieve vrouwe enen mensche...; $\left[1^{\mathrm{v}}-4^{\mathrm{r}}\right]$ 'Dit ghebet salmen lesen als men ten heiligen sacrament sal gaen...'; [4 $4^{\mathrm{v}}$ ] 'dit sijn drie paeter noster van der heiliger drivoldicheit...'; [5 $\left.5^{\mathrm{r}}-6^{\mathrm{v}}\right]$ ' $\mathrm{O}$ alre heilichste maghet Maria ghebenedide moeder ons heren Ihesu Christi voer dine heilighe voete val ich neder ...'; [ $\left.7^{\mathrm{r}}-7^{\mathrm{v}}\right]$ 'Weest ghegroet ende verblyt gloriose vrouwe, heilighe moder gods Maria...'; [ $\left.7^{\mathrm{v}}-8^{\mathrm{r}}\right]$ 'O Maria, ontfermt u mynre, du, dy ghenoemt biste een moder...'; [ $\left.8^{\mathrm{r}}\right]$ 'O saele des groten conincks ende blinckende poerte des hemels, coningine alder enghelen...; [ $\left.8^{\mathrm{r}-\mathrm{v}}\right]$ 'Och Maria, ic heb tot u gheropen als ic bedroeft was ende sy heeft verhoert...'; [8v] 'O Maria, sterre des meers, verliechterse alder werelt...'; [8 $\left.8^{v}\right]$ 'Reycke uut tot ons dyn aerme ionffrouwe Maria...'; [9r] 'O coningine des hemels ende vrouwe der enghelen...'; [9r $-11^{\mathrm{r}}$ ] 'In dien daghe dattu keerdes dyn alder claerste aenghesicht boven ons soe salstu ionffrouwelijke moder ons verblijden...'; $\left[11^{\mathrm{r}}-12^{\mathrm{r}}\right]$ 'O heilige apostel Peter ende vrint gods...'; [12 $\left.{ }^{\mathrm{v}}\right]$ blank. 


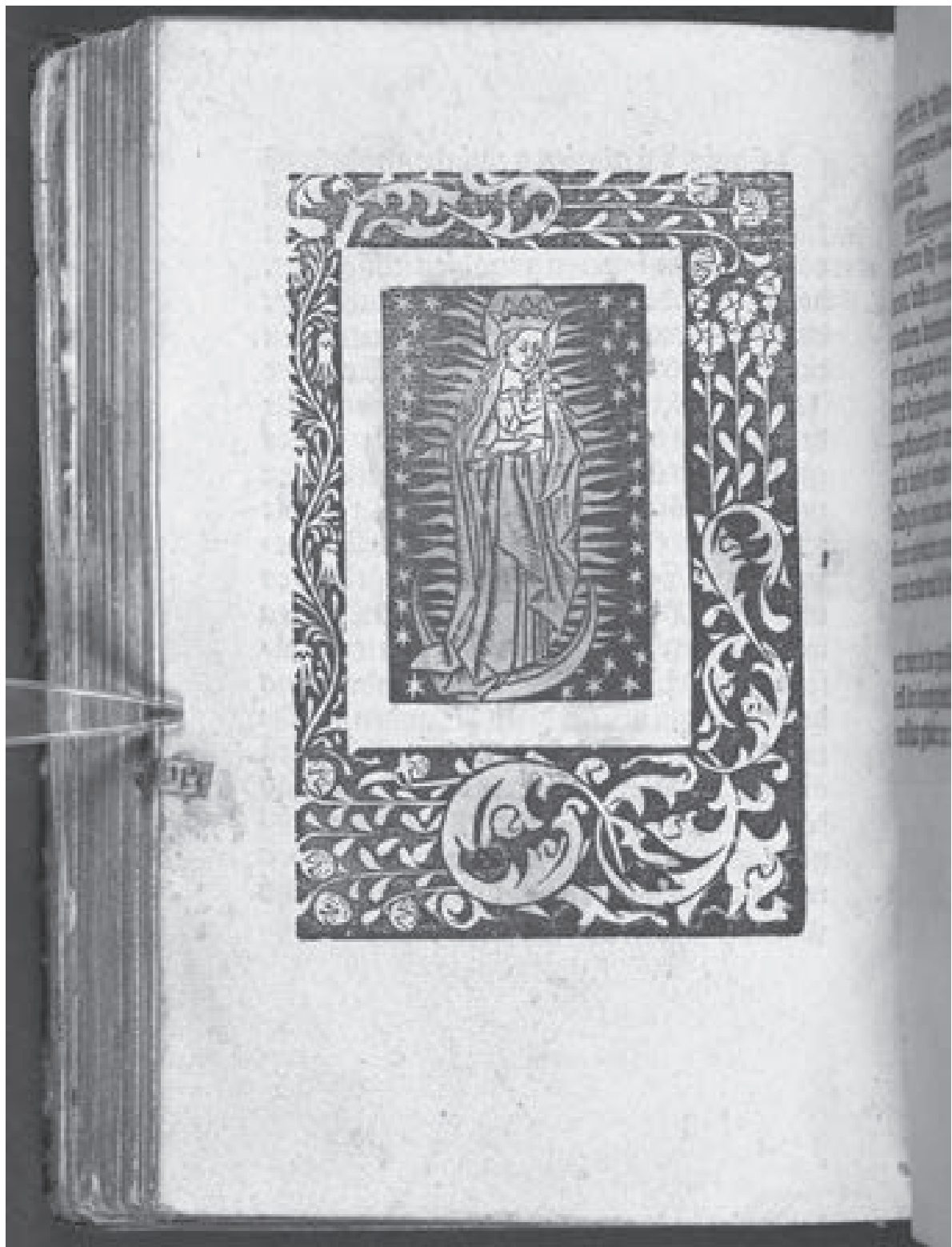

Figure 4. 'The woodcut of Mary and the Child standing on a crescent moon and clothed with the sun next to the fourth penitential psalm taken from the Psalter of our Lady, with yellow colour and bookmark', London, British Library, IA.49933, fol. 13v. Copy of the edition by Claes Leeu (Antwerpen, 29 November 1487). (c) The British Library Board. 


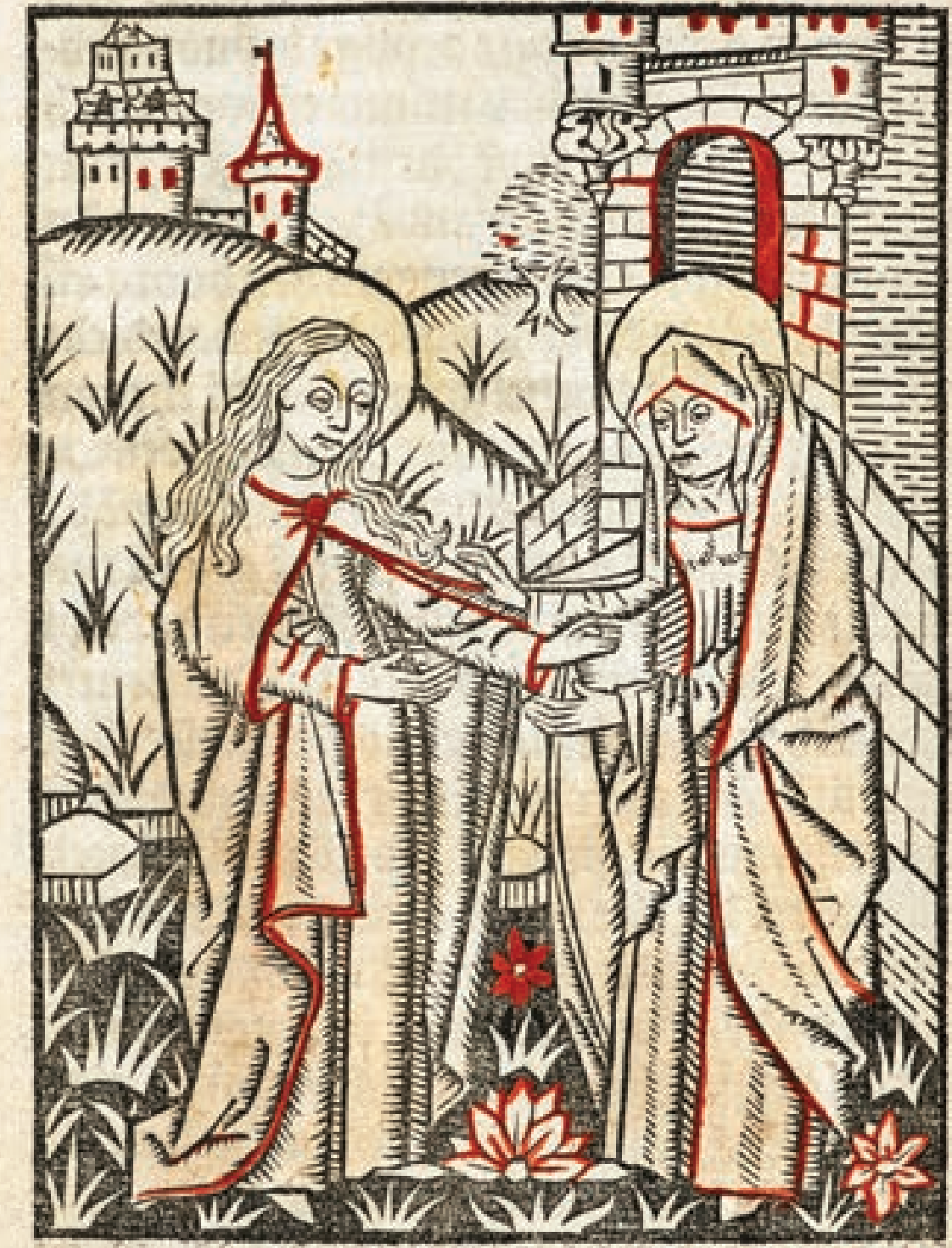

Plate I. 'The Visitation woodcut. Red ink emphasizes contours and details and Mary's and Elizabeth's garments and halos have been touched up with a yellow hue', London, British Library, IA.49933, fol. e3 ${ }^{v}$. Copy of the edition by Claes Leeu (Antwerpen, 29 November 1487).

(C) The British Library Board. 


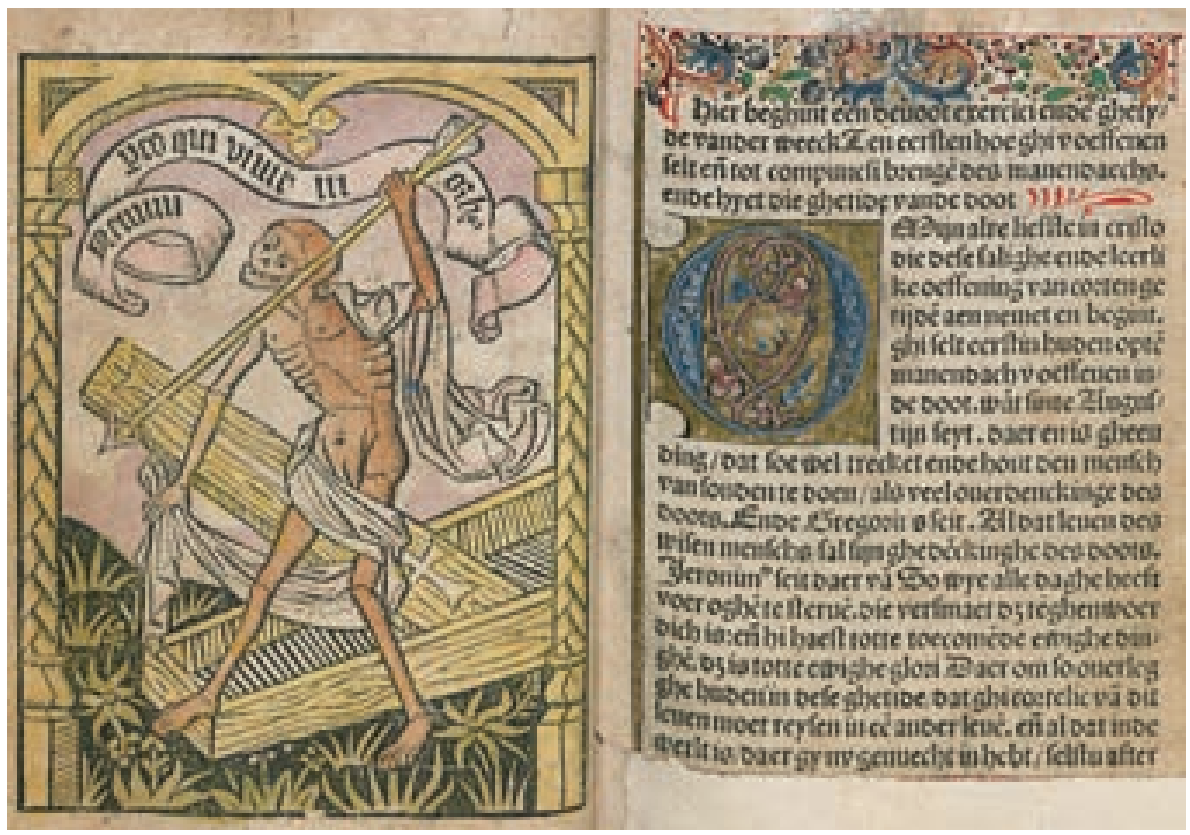

Plate II. 'Start of the meditative text for Monday in one of the copies of the first edition by Gerard Leeu. Coloured woodcut, gold leaf initial and border, and painted upper border with gold leaf details', Antwerpen, Ruusbroecgenootschap, L.P. 20/m1099E4, fols a $7^{\mathrm{v}}-\mathrm{a} 8^{\mathrm{r}}$.

(Gouda, 1483, before 10 December). Reproduced with permission. 


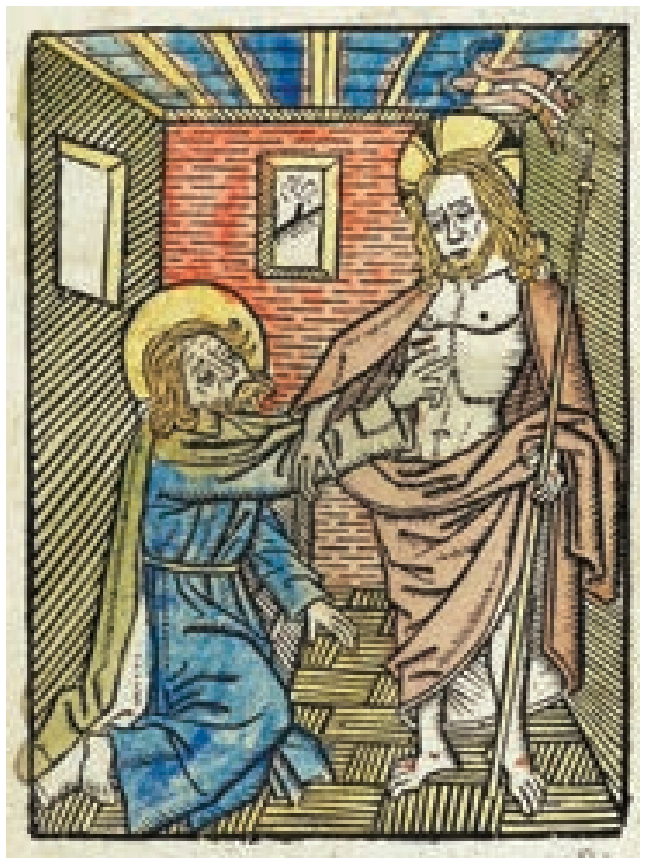

Plate III. 'Colouring in the Cambridge copy of the 1496 edition by the Gouda Collaciebroerders. The Incredulity of St Thomas (Plate IIIa) and Pentecost

(Plate IIIb). The blue of Thomas's garment and of the ceiling has been added over lighter shades. The Pentecost woodcut represents the 'first stage' of colouring', Cambridge, University Library, Inc.5.E.3.10[2890], fols $s 2 \mathrm{v}$ and $\mathrm{s} 5 \mathrm{v}$. Reproduced by kind permission of the Syndics of Cambridge University Library.

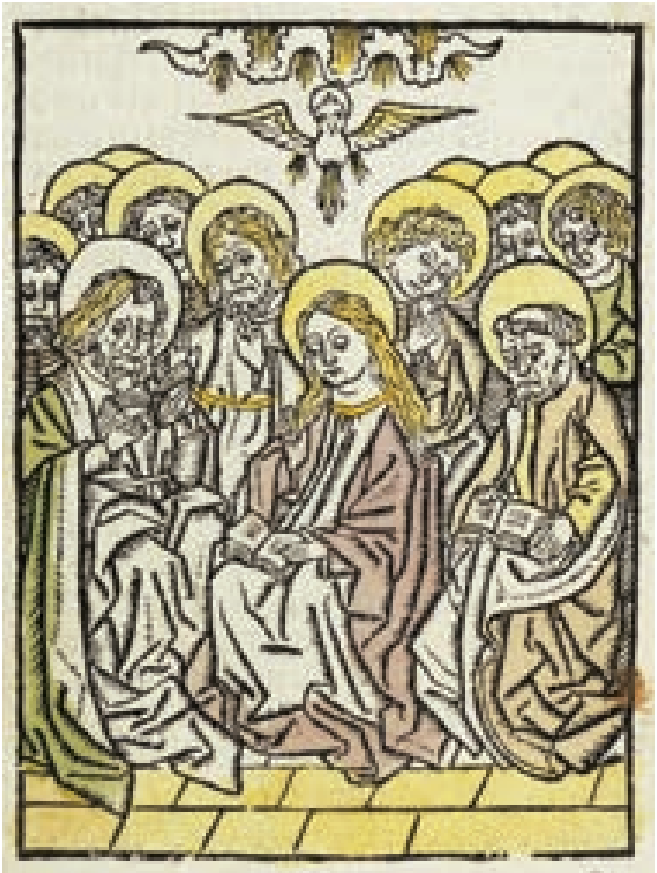



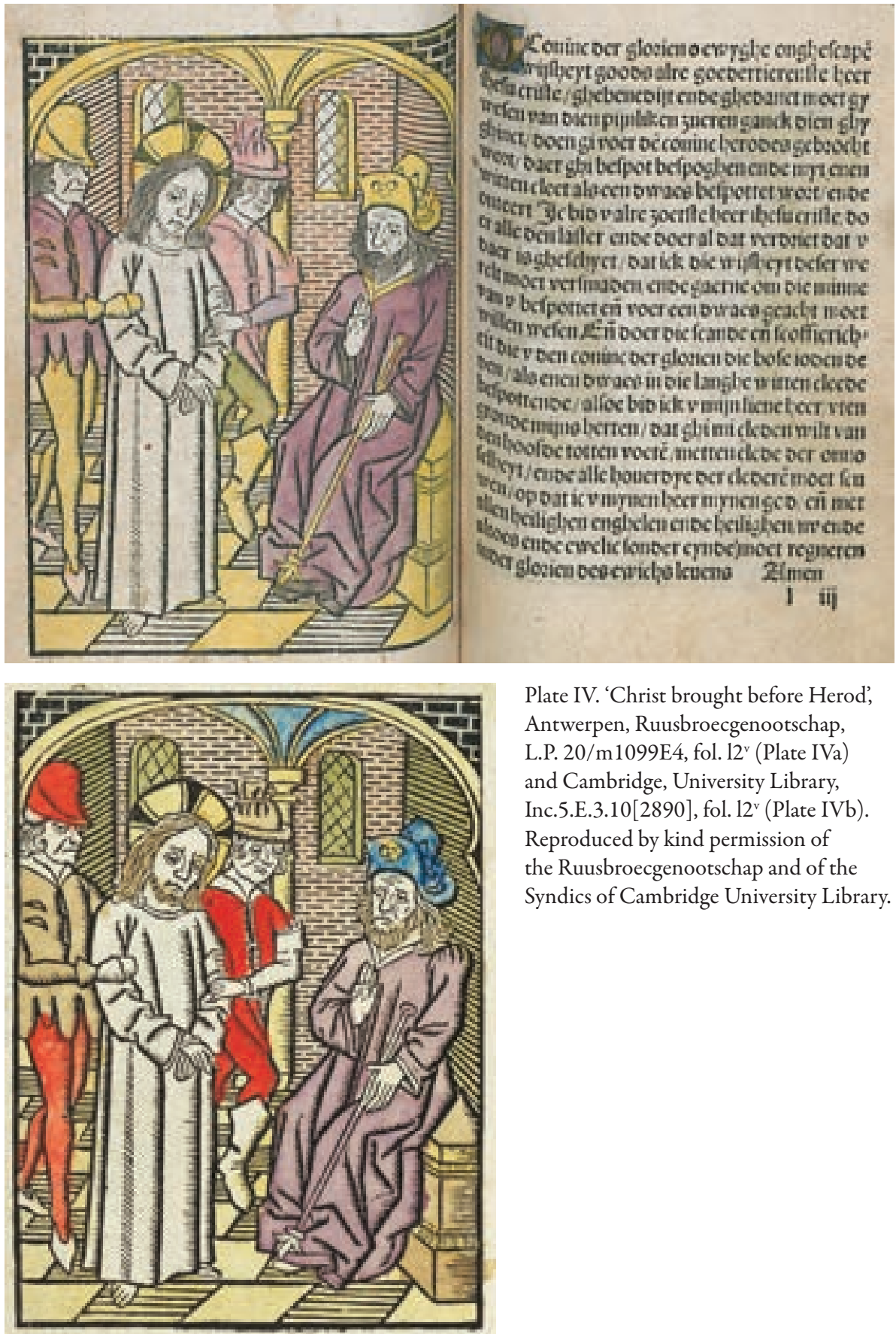

Plate IV. 'Christ brought before Herod', Antwerpen, Ruusbroecgenootschap, L.P. 20/m1099E4, fol. 12v (Plate IVa) and Cambridge, University Library, Inc.5.E.3.10[2890], fol. 12v (Plate IVb). Reproduced by kind permission of the Ruusbroecgenootschap and of the Syndics of Cambridge University Library. 


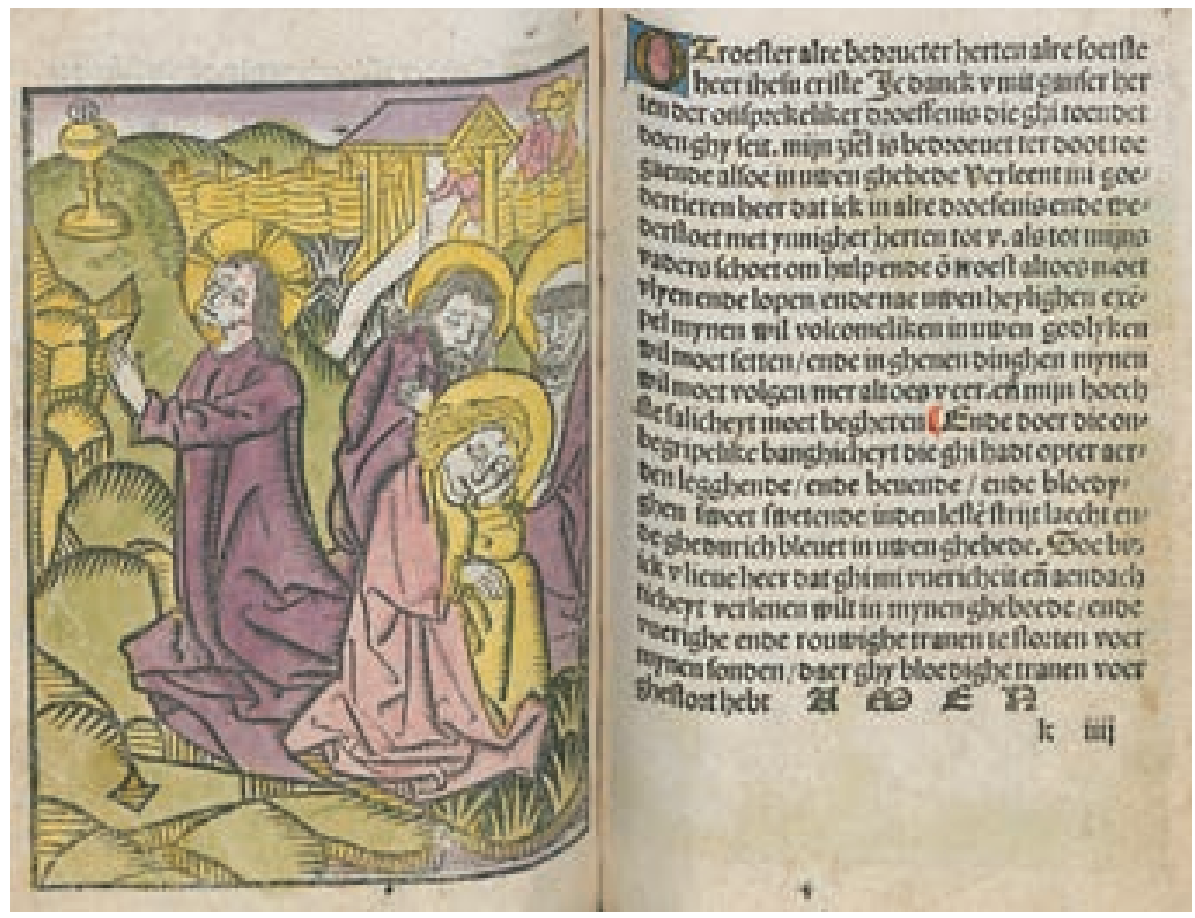

Plate V. 'The agony in the garden of Gethsemane. Coloured woodcut in the Antwerp copy of Leeu's first edition', Antwerpen, Ruusbroecgenootschap, L.P. 20/m1099E4, fols k3 ${ }^{\mathrm{v}}-\mathrm{k} 4^{\mathrm{r}}$. (Gouda, 1483, before 10 December). Reproduced with permission. 


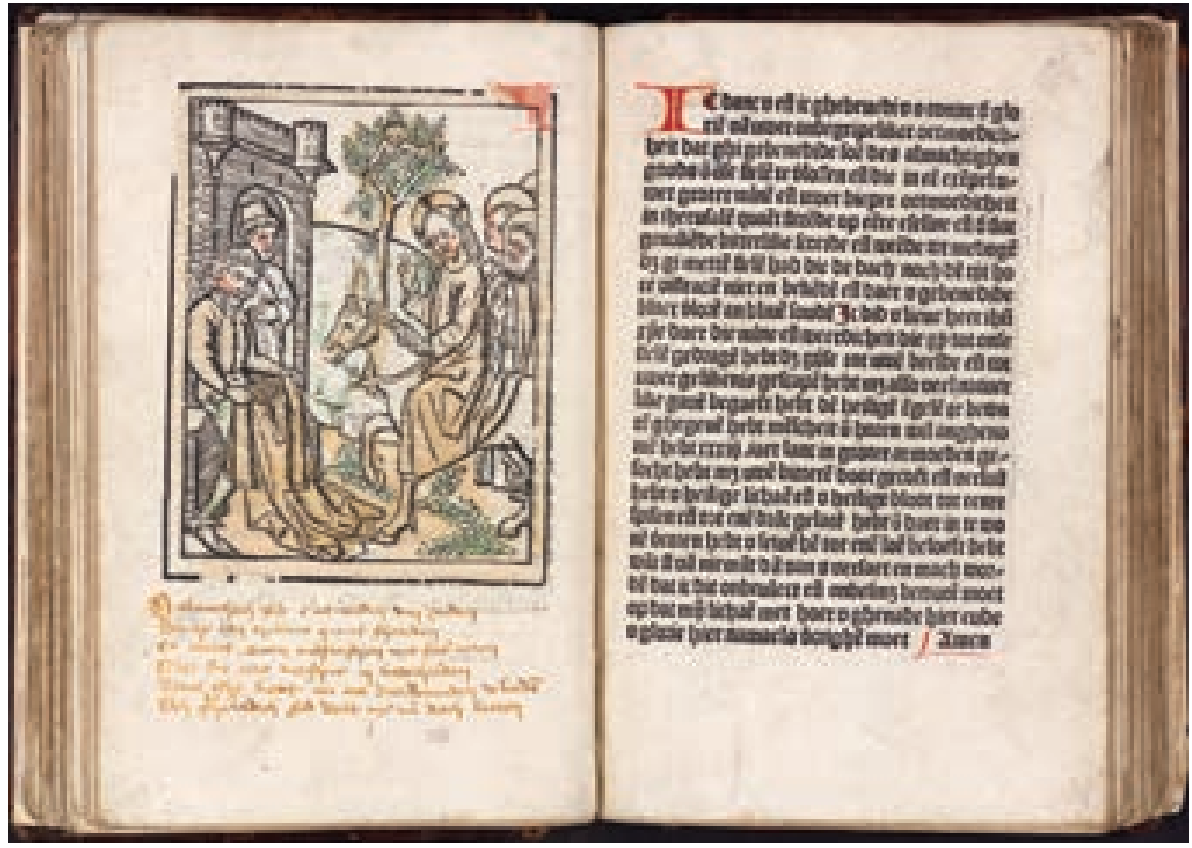

Plate VI. 'Entry into Jerusalem. Coloured woodcut with handwritten poem in the only extant copy of Jacob Bellaert's 1486 Haarlem edition. The colouring has been partially removed', Amsterdam, Universiteitsbibliotheek,

Bijzondere Collecties, Inc. 421, fols h3 $3^{\mathrm{v}}-\mathrm{h} 4^{\mathrm{r}}$.

Reproduced with permission.

hands and thus appear to have been either a collective effort and/or collected over time, reflecting the interests (of a group?) of readers with a predominant focus on Marian devotion. ${ }^{34}$ The inclusion of communion prayers, often found in books of hours but not incorporated into the Devout Hours, reflects a need for these texts and suggests that the copy was also used during Mass. Furthermore, the female form of the Middle Dutch word for sinner (sondersse) in these prayers points to a female scribe and setting. ${ }^{35}$ Yet another user brought the codex up-todate in the early sixteenth century by adding a slightly smaller leaf after the Adoro $T e$ prayer with the handwritten text of the three extra verses that were added to

${ }^{34}$ Hands: $1\left[1^{\mathrm{r}}-1^{\mathrm{v}}\right] ; 2\left[1^{\mathrm{v}}-4^{\mathrm{r}}\right] ; 3\left[4^{\mathrm{v}}\right] ; 4\left[5^{\mathrm{r}}-6^{\mathrm{v}}\right] ; 5\left[7^{\mathrm{r}}-11^{\mathrm{r}}\right] ; 6\left[11^{\mathrm{r}}-12^{\mathrm{r}}\right]$.

${ }^{35}$ London, BL, IA.49933, fol. [3r] 'die du gheleden hebste aenden heiligen cruce om mij arme sondersse'. 
the prayer in 1503 (Fig. 5). ${ }^{36}$ This way she (and other women?) had the latest version at their disposal.

The only extant copy of Claes Leeu's edition thus contains several layers of material evidence that point to a focus on Mary in the devotion of the reader(s): the added quires with predominantly prayers to Mary are consistent with the colour added to the woodcuts of Mary clothed with the sun next to the short psalms, the bookmarks mounted onto some of these leaves and the special attention paid to the Marian prayer ascribed to St Bernard at the end of the book. Due to the various users involved in customizing the book we might think of a small circle of devout urban readers, possibly members of one family or a religious confraternity. In what kind of setting the reader(s) practised their Marian directed devotion exactly, remains uncertain.

\section{Colour}

The colouring of woodcuts and other additions to images in religious incunabula from the Low Countries, such as inscriptions, have hitherto not received a lot of attention. ${ }^{37}$ More work has been done with regard to colour and other additions to the surface of woodcuts printed on single sheets. Concerning the interpretation, function, and influence on viewing practices of alterations and additions such as colouring and writing in prints, the work by art historians Peter Schmidt and David Areford is seminal..$^{38}$ The idea of an 'archaeology of the printed image', which in turn was inspired by the 'archaeology of the manuscript', can also be transferred to incunabula, and illustrated incunabula in particular. ${ }^{39}$ As we have seen, layers of handmade additions added to these books by readerviewers provide clues about the way text and image functioned in readers' hands. ${ }^{40}$ Colouring seems to be a particularly important 'reception layer'. The colouring

${ }^{36}$ London, BL, IA.49933, after fol. c7. From circa 1483 this prayer consisted of five verses (the text that Leeu put to press). In 1503 three extra verses were added to the prayer. I would like to thank Sanne de Vries (Leiden University) for this information.

${ }^{37}$ Van Delft, 'Illustrations in Early Printed Books', discusses two coloured copies of a Dutch book of hours printed in Paris. General observations in Goedings, 'Afsetters en meester-afsetters', pp. $48-52$.

38 Areford, 'Introduction', Areford, 'The Image in the Viewer's Hands' and Areford, The Viewer and the Printed Image and, for example, Schmidt, 'Beschrieben, bemalt, zerschnitten'.

39 Areford, 'Introduction', pp. 2-3.

${ }^{40}$ Cf. Areford, 'The Image in the Viewer's Hands', p. 7. 


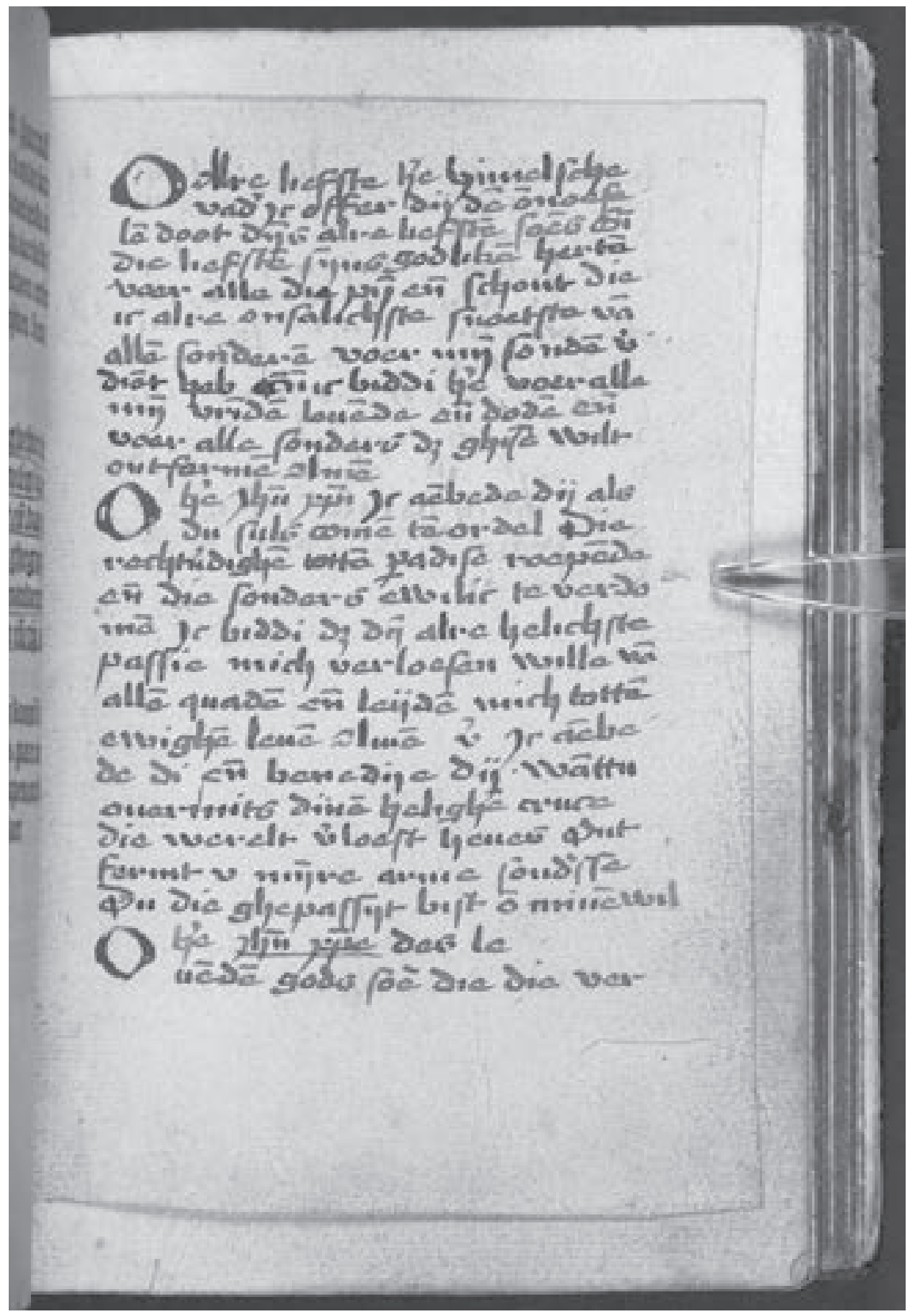

Figure 5. 'The Adoro Te prayer brought up-to-date by one of the users', London, British Library, IA.49933, leaf inserted after fol. c7. Copy of the edition by Claes Leeu (Antwerpen, 29 November 1487). (c) The British Library Board. 
we have encountered thus far is simple and in its function seems close to a form of 'pictorial annotation'. Even in works such as the Devout Hours colouring was often more sophisticated, however, and although until now largely ignored, essential to the way the book - as a unity of text and image - was experienced by readerviewers. Out of the total of seven extant copies, five copies contain some form of colouring. ${ }^{41}$ The colouring and pallet used differs from copy to copy - there was thus apparently no template that colourists followed - and in all copies colour has been applied freehand, without the use of stencils. ${ }^{42}$

The oldest copy with coloured woodcuts is one of the two copies of the first edition by Gerard Leeu (Gouda), nowadays in the library of the Ruusbroec Institute in Antwerp. ${ }^{43}$ Originally, the copy was bound together with a fifteenthcentury parchment manuscript with a Middle Dutch West-Flemish translation of the second book of the Imitatio Christi ${ }^{44}$ During restoration manuscript and print were separated, which happened more often when medieval material was made to fit modern distinctions between manuscript and print. ${ }^{45}$ This practice ignores, however, late medieval reality and materiality. In the case of the Antwerp copy, the manuscript with the twelve chapters from the work by Thomas a Kempis, bound in front of the printed book, provided a profound introduction to inner life that the reader then could take up further and practice week after week in the Devout Hours. At times he would have returned to Kempis's work for a more profound Christocentric contemplation on the withdrawal from the world, purging his conscience and intention and deepening his spiritual growth. Moreover, the manuscript points to a milieu in which these texts circulated and (older) manuscript material was available. ${ }^{46}$

Together with the gold leaf initials, careful rubrication applied with red and blue ink and two handwritten Latin (liturgical) prayers — a rhymed prayer (hymn)

${ }^{41}$ Antwerpen, RG, L.P. 20/m1099E4; Amsterdam, UB, Inc. 421; London, BL, IA.49933; Cambridge, UL, Inc.5.E.3.10[2890]; Den Haag, KB, 150 E 3.

42 On the use of stencils Primeau, 'Colouring within the Lines', and Primeau, 'The Materials and Technology of Renaissance and Baroque Hand-Colored Prints', pp. 66-68.

43 Antwerpen, RG, L.P. 20/m1099E4. Reypens, 'Rond een Antwerpse druk'.

${ }^{44}$ Nowadays Antwerpen, RG, MS 202. The manuscript is dated to the middle or second half of the fifteenth century. See Reypens, 'Een onbekend vijftiendeeuws handschrift'.

45 A copy of Gerard Leeu's Tafel des kersteliken levens (Den Haag, KB, 169 G 94) was for example bound together with a manuscript of a life of St Jerome, nowadays Den Haag, KB, MS 129 G 8.

${ }^{46}$ Because the recto of the manuscript's first leaf contains the end of a sermon by Goswinus Hex (Eene oufeninghe vander gracien gods) it is probable that the owner acquired the second book of the Imitatio Christi as an already existing unit. 
to Mary added after the end of the penitential psalm for Friday and canticle(s) for the feast of the eleven thousand virgins on the verso of the last leaf, written by the same hand but added over time - the Imitatio Christi-manuscript points to a wellto-do and well-educated layman who actively used the Devout Hours in his pious practice and looked for material that could function as a supplement to the texts in the printed book. ${ }^{47}$ The execution of the gold leaf initials and of the borders on the page where the hours of Death starts (Plate II) is reminiscent of decoration found in devotional manuscripts made in Bruges (Fig. 6). The place of decoration is consistent with the language of the manuscript with the Imitatio Christi and we might thus, in all probability, locate our pious layman in Bruges or its surroundings. Leeu's books were sold in Antwerp already in the late 1470s, and in 1484 he registered as a member of the St John's guild in Bruges. ${ }^{48}$ In later years he appointed several (international) business agents during the Easter fair at Bergen op Zoom. ${ }^{49}$ Thus, it is not surprising that someone from West Flanders bought a copy of the first known edition of the Devout Hours and had it decorated in Bruges.

The painting of the woodcuts, executed consistently throughout the copy in yellow, purple, pink, green, dark grey, light red, and brown hues, was probably executed by a different craftsman than the initials and border decoration. Both pigments and technique used are different. ${ }^{50}$ Generally, colour has been applied without shading, which is only used sporadically, for example to heighten the folding of cloth. The colourist has consistently added shade to windows in order to add depth to the image. The research by Jan van der Stock has revealed that in 1512 the Antwerp printer Andriaan Janssoens 'de Verlichter' had materials for colouring woodcuts in his workshop. ${ }^{51}$ Van der Stock has suggested that Leeu

${ }^{47}$ Antwerpen, RG, L.P. 20/m1099E4. Both handwritten texts have a title in Dutch: fol. $\mathrm{m} 7^{\mathrm{r}}$ 'van onser vrouwe / Stella poli, regina soli, tu proxima soli / Ave maria gratia(?) Digna coli sine nube doli...' (for these lines see Mone, Hymni Latini, p. 324, and Blume and Dreves, Analecta Hymnica, p. 145.37-38) and fol. t 8 v 'Jhesus Maria Vanden xi dunest[!] maeychden Media autem nocte clamor factus est ecce sponsus venit exite obviam ei prudentes virgines aptate vesteras lampades quia sponsus venit Christus...' (Matthew 25.6-7, cf. http://cantusindex.org/id/605044a).

48 Goudriaan and Willems, Gheraert Leeu, p. 19 and 23; Hellinga's, Fifteenth-Century Printing Types, p. 69; Dewitte, 'Het Brugse St.-Jans en St.-Lucasgilde der librariers 1457, 1469', p. 339; Dlabačová, Literatuur en observantie, pp. 210-11, cf. also Hellinga, 'Gheraert Leeu, Claes Leeu, Jacob Bellaert, Peter van Os van Breda', p. 285 n. 7.

49 Gnirrep, 'Relaties van Leeu', pp. 194-98. Brinkman, 'De Const ter perse', p. 161.

50 Cf. Primeau, 'The Materials and Technology of Renaissance and Baroque Hand-Colored Prints', esp. pp. 63-65 and Oltrogge, 'Illuminating the Print', on different techniques and effects of colour in prints.

${ }^{51}$ Van der Stock, Printing Images in Antwerp, p. 98. 


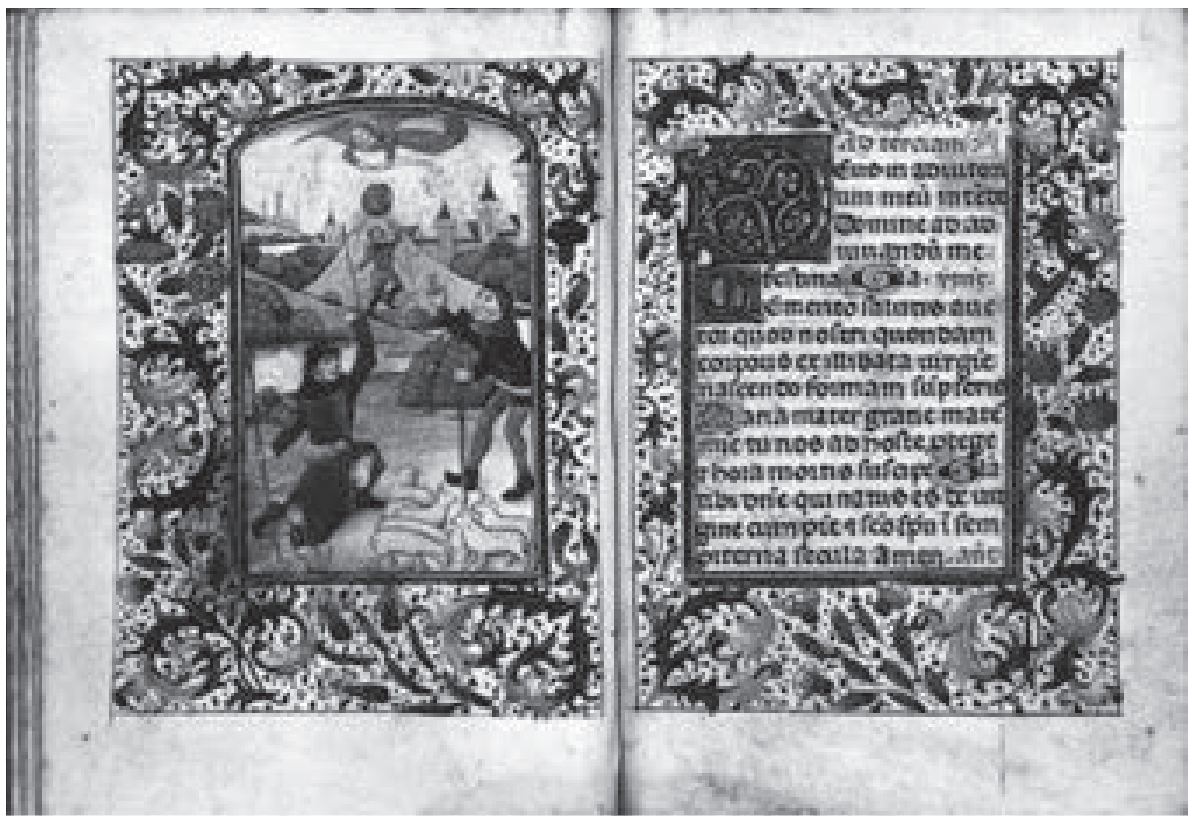

Figure 6. 'Book of Hours, use of Rome, Latin. West Flanders, Bruges (?),' 's-Heerenberg, Huis Bergh, MS 29, fols $60^{v}-61^{\mathrm{r}}$. Third quarter fifteenth century. Reproduced with permission.

might have become a member of the guild of $\mathrm{St}$ Luke because he used materials in his shop that were used by painters. ${ }^{52}$ Perhaps some copies of Leeu's editions were coloured under his auspices, as was the case with Hartmann Schedel's Nuremberg Chronicle (1493), printed by Anton Koberger in Nuremberg and distributed in coloured and uncoloured copies - the former twice as expensive as the latter. ${ }^{53}$ The suggestion that Leeu was somehow involved in colouring might be confirmed if two or more copies with (near) identical (style of) colouring are found. So far, however, colouring seems to differ from copy to copy in Leeu's editions, and in any case in the copies of the Devout Hours. The colouring might have been added by a workshop specialized in (manuscript?) illumination or one combining a number of activities linked to book and print production, possibly also in Bruges. ${ }^{54}$

52 Van der Stock, Printing Images in Antwerp, pp. 29-30; 35-43.

53 Dackerman, ed., Painted Prints, cat. 7, pp. 102-04 and Wilson, Making of the Nuremberg Chronicle, pp. 229-37. The author owned a magnificently coloured copy (p. 207).

${ }^{54}$ In Antwerp a Jan van den Driele (from 1494 onward) combined his activity as a copyist with book illumination, bookbinding and book selling, see Gnirrep, 'Relaties van Leeu', p. 195. It is likely that someone like van den Driele would also have coloured woodcuts. On print colourists 
Both surviving copies of the last known edition of the Devout Hours (Collaciebroeders, Gouda, 3 October 1496) have also been coloured. The copy kept in Cambridge, University Library, contains a sixteenth-century owner's inscription by, in all probability, a layman. ${ }^{55}$ The images in this copy, bound in an early-sixteenth-century binding, ${ }^{56}$ have been coloured with transparent purple, (dark) blue, yellow, brown, (bright) red, and green. The bright red and dark blue are more opaque and similar to the pigments used for rubrication and initials. These two colours are applied more crudely and at times over another, lighter colour (Plate IIIa). ${ }^{57}$ Possibly, the red and blue were not part of the original pallet and were added in a later stage (during the process of rubrication?), perhaps because the colouring was deemed too pale. It is also conceivable that the colouring was consciously planned this way in order to make the preparation and use of pigments more efficient - in this case the 'first' colourist, working with pale, transparent colours, deliberately left garments and details uncoloured, as is still the case in for example the Pentecost woodcut (Plate IIIb). ${ }^{58}$ This kind of question is difficult to answer yet significant for our understanding of the procedures involved in handmade finishes to incunabula and the meaning of colour. It is important to be aware of the fact that colouring could be the result of the work of more than one person, adding yet more layers to the already collective nature of an illustrated book. ${ }^{59}$

Both the colourists of the Antwerp and Cambridge copies incorporate the colour of the paper into their pallet, usually for skin (faces and hands). One of the most effective uses of the white of the paper in the Devout Hours can be found in these copies in the image of Christ before Herod (Plate IV). In the adjacent prayer, the devotee speaks multiple times of the white garment Christ was dressed in:

(Briefmaler) in Germany Dackerman, 'Painted Prints in Germany and the Netherlands', pp. 15-26.

55 On the verso of the flyleaf in the back we read 'Dijt boeck hoert toe Evert (?)'. Although the entire annotation is written in the same ink, the name was probably written by another hand and might therefore use different letterforms inconsistent with the rest of the annotation.

${ }^{56}$ Blind stamped brown leather over wooden boards with images of a pelican wounding its breast to feed its young. Maculature in front (liturgical manuscript, Latin, fifteenth century, Low Countries) and back (liturgical, Latin, twelfth century). McKitterick, 'Tanned Calf over Wooden Boards'.

${ }^{57}$ Examples on fols $\mathrm{k} 2^{\mathrm{v}}$ (Christ washing the feet of the apostles), $\mathrm{n} 2^{\mathrm{v}}$ (Christ crowned with thorns), $\mathrm{n}^{\mathrm{v}}$ (Christ disrobed), $\mathrm{s}^{\mathrm{v}}$ (The incredulity of St Thomas), and $\mathrm{t} 4^{\mathrm{v}}$ (Last Judgment).

${ }^{58}$ Cambridge, UL, Inc.5.E.3.10[2890], fol. $\mathrm{s}^{\mathrm{v}}$. Other examples include the Agony in the Garden of Gethsemane (k3 ${ }^{\mathrm{v}}$ ) and the Arrest of Christ $\left(\mathrm{k} 5^{\mathrm{v}}\right)$.

59 Analysis of the pigments could provide more certainty about the colouring process. See e.g. Primeau, 'The Materials and Technology of Renaissance and Baroque Hand-Colored Prints', pp. 55-63 and Oltrogge, 'Illuminating the Print'. Cf. Chartier, 'Afterword', p. 182. 
O coninc der glorien, o ewyghe onghescapen wijsheyt goods, alre goedertierenste heer ihesu christe, ghebenedijt ende ghedanct moet gy wesen van dien pijnliken, zueren ganck dien ghy ghinct doen gi voer den coninc herodes gebrocht wort, daer ghi bespot, bespoghen ende myt enen witten cleet als een dwaes bespottet wort ende onteert. [...] Ende doer die scande ende scoffiericheit die u, den coninc der glorien, die bose ioden deden, als enen dwaes in die langhe witten cleede bespottende, alsoe bid ick $\mathrm{u}$, mijn lieve heer, uten gronde mijns herten, dat ghi mi cleden wilt vanden hoofde totten voeten metten clede der onnoselheyt.

(Oh King of glory, oh eternal uncreated wisdom of God, most merciful Lord Jesus Christ, you should be blessed and thanked for your agonizing, grievous journey that you went when you were brought before king Herod, where you were mocked, spat at and with a white robe ridiculed and dishonoured as a fool. [...] And through the disgrace and humiliation that has been done to you, King of glory, by the wicked Jews, who ridiculed you as a fool dressed in that long white garment, so I pray to you, my dear Lord, from the bottom of my heart, that you shall dress me from top to toe with the garment of innocence.)

The colouring augments the meaning of the image and helps the reader to focus on the garment that is central to the event, the prayer, and to the metaphor used in the devotee's request. In this case colour strengthens the relationship between image and text and further assists the reader in emulating Christ's meekness. The combination of text and image even compelled one of the reader-viewers of the Antwerp copy to pierce the eyes of the two soldiers (Plate IVa). Thus, he/ she physically interacted with the book in a performative act, altering the image irreversibly.

In general, colour adds depth and definition to space, makes it easier to distinguish individuals in groups and to identify them in subsequent images. St John and Mary, for example, can be located instantly as they are made recognizable by their blond hair and red robe (St John) and blue garment (Mary) in sequential images in the second copy of the edition by the Gouda Collaciebroeders, nowadays kept in the Koninklijke Bibliotheek in The Hague. ${ }^{60}$ Colour thus also strengthens the iconography of woodcuts. Even though a template

${ }^{60}$ Den Haag, KB, 150 E 3. This copy can be consulted via Early European Books, http:// eeb.chadwyck.co.uk/. See in particular the prayer sequence for Saturday, starting with the Crucifixion $\left(\right.$ fols $\left.\mathrm{p} 3^{\mathrm{v}}-\mathrm{q} 1^{\mathrm{r}}\right)$. With all woodcuts fully coloured in a rich pallet the Den Haag copy contains the most elaborately executed colouring. The copy has rubrication and red initials with alternately blue and purple pen flourishes. Small painted borders, executed in a Ghent-Bruges style, have been added to the impressions of the woodcut of Mary clothed in the sun for which the Collaciebroeders used a different woodblock from the one use by Leeu (except for the last prayer on fol. $\mathrm{t}^{\mathrm{v}}$ ). See also De vijfhonderdste verjaring, pp. 450-52. 
was probably not available, colourists clearly followed certain (iconographic) conventions. Other examples include Christ's gown, usually coloured purple, and the image of hell, which is multi-coloured, probably to enhance its confused state and horrors. ${ }^{61}$ The possible interaction and discrepancies between woodcut colouring, manuscript miniatures, and even panel painting needs further research. In manuscripts of the Devout Hours Christ's gown, for example, is usually painted in a grey(ish) colour instead of the purple colour often found in copies of the printed editions. ${ }^{62}$ Moreoever, artists and artisans could work with various media: the well-known Antwerp painter Quentin Massys (c. 1466-1530) started his career as a print colourist. ${ }^{63}$

Apart from strengthening the meaning and expressive power of woodcuts, colour can also add pictorial elements to the printed image. Because the medium of the woodcut possessed limited means to portray blood, perhaps the most frequently found addition to impressions of religious woodcuts are drops, streaks, and streams of this bodily liquid. ${ }^{64}$ The fact that red ink was frequently at hand for rubrication has resulted in numerous Passion scenes in early printed Netherlandish books overflowing - at times excessively - with blood. In the already discussed copy of Claes Leeu's edition the red ink was occasionally added to Christ's wounds and the arma Christi. ${ }^{65}$

In the prayer adjacent to the woodcut of the Agony in the garden of Gethsemane, the devotee thanks Christ for the inexpressible sadness Christ showed when he spoke the words 'My soul is overwhelmed with sorrow to the point of death' (mijn ziel is bedroevet ter doot toe) (Matthew 26.38). In the second half of the prayer the devotee requests to be granted the same fervour in his prayer as Christ:

Ende doer die onbegripelike banghicheyt die ghi hadt opter aerden legghende ende bevende ende bloedyghen sweet swetende inden lesten strijt laecht ende ghedurich blevet in uwen ghebede. Soe bid ick u, lieve heer, dat ghi mi vuericheit ende aendachticheyt verlenen wilt in mynen ghebeede ende vuerighe ende rouwighe tranen te storten voer mynen sonden daer ghy bloedighe tranen voer ghestort hebt. Amen.

${ }^{61}$ The meditative text adjacent to the image of hell starts with the instruction 'Meert oeck $\mathrm{u}$ inwendighe oghe opten helschen coninckrijc' (Also cast your inner eye on the kingdom of hell). See n. 20-21 above. Cf. Goedings, 'Afsetters en meester-afsetters', pp. 48-52, on a copy of an edition of Belial by Bellaert.

${ }^{62}$ London, British Library, MS Add. 20729; Den Haag, KB, MS BPH 79; Den Haag, KB, MS 135 E 19; Princeton, UL, MS Garrett 63.

${ }^{63}$ Dackerman, 'Painted Prints in Germany and the Netherlands', p. 30.

${ }^{64}$ Cf. Areford, 'The Image in the Viewer's Hands', p. 57. Dackerman, ed., Painted Prints, p. 138.

${ }^{65}$ See n. 27 above. 
(And through the inconceivable anxiety that you had lying on earth and trembling and sweating bloody sweat in your last agony and persevering in your prayer, so I pray to you, dear Lord, that you may lend me fervour and zeal in my prayer and [that I may] shed ardent and sorrowful tears for my sins for which you have shed tears of blood. Amen. ${ }^{66}$

The colourist of the copy kept in Antwerp added the bloody sweat to Christ's forehead, a detail that was important in the devotee's prayer (Plate V). ${ }^{67}$ In the copy of Bellaert's edition a red hue also seems to have added focus on Christ's bloody sweat and tears, through which the devotee was asking for more passion in his own prayer and which he was to 'mirror' in his prayer. ${ }^{68}$ As Christ's agony in the garden of Gethsemane, and in particular his sweating of blood, was also one of the six or seven of Christ's bloodlettings that formed one of the many popular devotional lists in the late medieval period, the red colour might have seemed essential to the image to at least some of the readers. One of the manuscripts that contain the prayers also follows this 'colour-convention', fulfilling the public's expectations (Fig. 7, Plate V). ${ }^{69}$ It might even have been the case that designers of woodcuts and/or woodcutters anticipated this kind of colouring. ${ }^{70}$

The coloured woodcuts in the books might not have served only as meditational instruments in relation to the text physically present in the same opening (e.g. as counterparts to the short prayer texts). At the end of the 'hour' on the Passion, to be read on Friday, the reader is encouraged to extend his meditation by literary following Christ during the events from the Last Supper onward:

Ist dat ghi tijt, plaets off stonde hebt dese ghetijde int lang te vertrecken, soe beghintse int avontmael, daer wast u vule voeten myt warm water des berouwes. Soe gaet dan voert int hoeffgen, ende ist moghelic dat god $\mathrm{u}$ die kelc des vegheviers off nemen wil, weest oec willich ende bereyt, ghevanghen ende ghebonden te werden om god, tgheloeff, u salicheyt, die penitenci te volharden. Aldus gaet voert ende volghet Jhesum nae die ghebonden gheleyt wort als een dieff in Annas huyse

\footnotetext{
${ }^{66}$ Antwerpen, RG, L.P. 20/m1099E4, fol. $\mathrm{k} 4$ r .

${ }^{67}$ Antwerpen, RG, L.P. 20/m1099E4, fol. k3 .

${ }^{68}$ Amsterdam, UB, Inc. 421, fol. $\mathrm{k} 3 \mathrm{v}$.

${ }^{69}$ Den Haag, KB, MS BPH 79, fol. $57^{\mathrm{r}}$.
}

${ }^{70}$ Certain (devotional) woodcuts were intended to be coloured; the addition of blood was required in for example a print of Christ on the Cross with Angels in which Christ's blood (to be added by hand) drips into chalices held by angels: Primeau, 'The Materials and Technology of Renaissance and Baroque Hand-Colored Prints', pp. 65-66. Cf. Oltrogge, 'Illuminating the Print', p. 303, and Dackerman, 'Painted Prints in Germany and the Netherlands', pp. 18-19. 


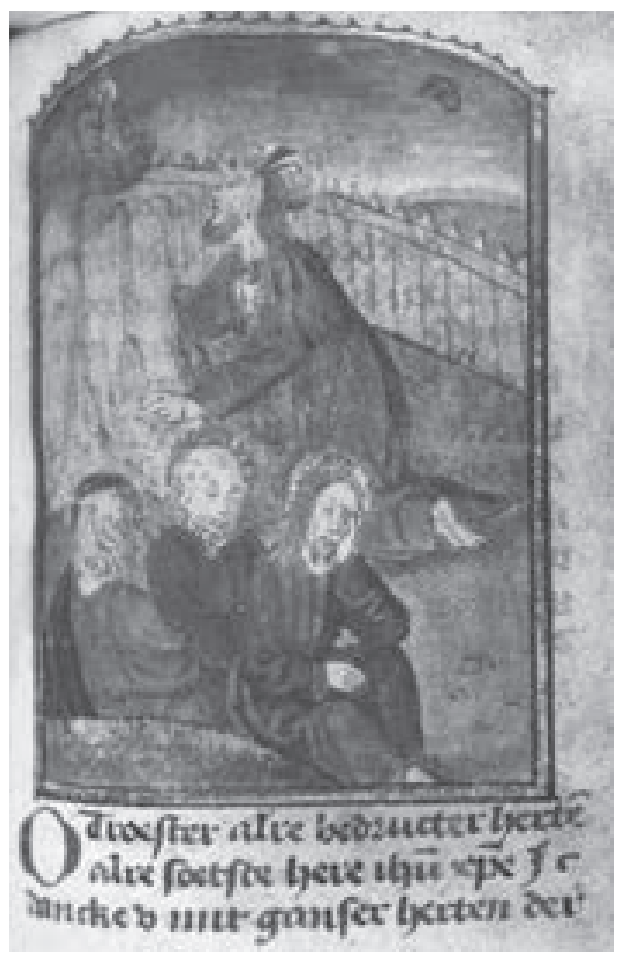

Figure 7. 'The agony in the garden of Gethsemane. Manuscript with the prayer cycle on salvation history from the Devout Hours, produced by one of the Masters of Hugo Jansz van Woerden', Den Haag, Koninklijke Bibliotheek, MS BPH 79 , fol. $57^{\text {r. }}$. . 1500 . Reproduced with permission.

[...] ende blijft altijt by hem, waer hy gaet, ter tijt toe dat hi verrijst ende van die doot weder op staet. Mocht gy aldus dese ghetijde houwen, het soude u baten ende nymmermeer rouwen.

(If you have the time, place or occasion to draw out this hour in length, so start in the [Last] Supper; there wash your soiled feet with warm water of repentance. And go forth in the garden, and if it is possible that God may want to take the chalice of purgatory from you, be also willing and prepared to be caught and tied up [and] to persevere [in] penitence for God, [for] faith and [for] your salvation. And so continue and follow Jesus who is led tied as a thief to Annas' house [...] and stay always with him, wherever he goes, until the time that he resurrects and resuscitates from death. May you thus keep this hour; it would be very helpful and never distress you. $)^{71}$

To support this meditation, the reader-viewer might have leafed backwards to the prayers for Thursday (the prayers for Thursday start with an image of the

71 Antwerpen, RG, L.P. 20/m1099E4, fols $17^{\mathrm{v}}-8^{\mathrm{r}}$. 
Last Supper which is followed by the washing of the disciples' feet and the agony in the garden of Gethsemane and they also include Christ before Annas), and forwards to the chapters that include prayers on Christ's death and resurrection and used the images there as a guideline for this strongly figurative meditation.

\section{Variations in Verse}

The only extant copy of the 1486 edition printed by Jacob Bellaert in Haarlem nowadays has subtle colouring in yellow, red, brown, green, and blue hues, but originally the colours would have been much more vivid and intense (Plate VI).$^{72}$ The removal and/or alteration of colour in later periods are yet other difficulties one should keep in mind when dealing with colour in incunabula. ${ }^{73}$

Apart from carefully applied rubrication and initials in red, the copy contains several short texts written by a number of users on leaves left - either partially or entirely - blank by the printer. At the end of the chapter for Monday, one of the readers added what seems to be an original poem on the meditative topic of that day, Death (Fig. 8). The poem is divided into two stanzas of sixteen lines. Because of its literary quality, which places the verses close to the sphere of the rederijkers (the chambers of rhetoric), it is worthwhile quoting at least the first stanza in full:

Och god als ic overpeyse

Die doot die nu niemant en spaert

Soe duchtic zeer voer myn reyse

Want ic binder niet op bereyt

$[\mathrm{V}]$ an welcker ic bin soe zeer verwaert

72 The colours have been removed as much as possible, as has also been done with many of the handwritten texts (see n. 81 below). Possibly this was done by the nineteenth-century owner and antiquarian bookseller F. Olivier (Brussels). The cloak of the father in the Throne of Grace, for example, appears to have been consistently coloured in dark blue, but this colour has been removed almost entirely. Remnants are visible on fols $\mathrm{b} 7^{\mathrm{v}}, \mathrm{c} 3^{\mathrm{v}}, \mathrm{c} 5^{\mathrm{v}}, \mathrm{d} 1^{\mathrm{v}}, \mathrm{e} 2^{\mathrm{v}}, \mathrm{e} 3^{\mathrm{v}}, \mathrm{e} 4^{\mathrm{v}}, \mathrm{f} 1^{\mathrm{v}}, \mathrm{f} 3^{\mathrm{v}}$, $\mathrm{h} 1^{\mathrm{v}}, \mathrm{k} 1^{\mathrm{v}}, \mathrm{o} 4^{\mathrm{v}}, \mathrm{p} 2^{\mathrm{v}}, \mathrm{p} 4^{\mathrm{v}}, \mathrm{p} 5^{\mathrm{v}}, \mathrm{q} 1^{\mathrm{v}}, \mathrm{r} 7^{\mathrm{v}}, \mathrm{t} 4^{\mathrm{v}}$. The dark green colour, which originally must have been almost opaque, has also been laboriously removed in most places (see plate VI ( $=\mathrm{h} 3 \mathrm{v})$, and for example fols $\mathrm{k} 1^{\mathrm{v}}$ and $\mathrm{k} 2^{\mathrm{v}}$ ). Cf. Bogaart, Geleerde kennis in de volkstaal, on colouring in the copies of Bellaert's edition of Van den proprieteyten der dinghen. Bellaert's copy of the Devout Hours is discussed in Kok, 'A Rediscovered Devote ghetiden', but her focus is on analytical bibliography and she mentions none of the handmade additions.

73 Cf. Dackerman, 'Introduction', pp. 2-3, on colouring as adultery and the removal of colour from prints. See also Schmidt, 'Beschrieben, bemalt, zerschnitten', p. 245, on the twentieth-century practice of removing any traces left by users from reproductions of prints in publications in order to represent the 'original', clean form of the woodcut. Cf. Jecmen, 'Color Printing and Tonal Etching', pp. 67-68. 
[Ic] bidde $\mathrm{u}$, heere god, om respyt

[To]t dat ic myn sonden hebbe verclaert

[W] ant ic en hebbe ure nochte sekeren tijt

[...] aes als ic ga dan overdincken

Die helle ende dat grote torment

Myn herte wil myn van vaere ontsincken

Die ewich is ende niet en eendt

Ic biddu, coninc omnipotent

Wilt my arme sondare niet versmaden

$[\mathrm{M}]$ yn ziele die es u testament

Ontfermt myns god doer wuer[? uwer] ghenade

(Oh God, as I ponder upon / death who now spares no one, / so I fear greatly for my journey / because I am not ready for it / of which I am distressed so deeply / I pray to you, Lord God, for respite / until I have accounted for my sins / because I do not have hour nor a sure time / ... thus, when I contemplate upon / hell and that great torture / my heart wants to sink away because of the terror / that is eternal and never ends / I pray to you, King almighty / do not scorn me, poor sinner / my soul is your last will / Have mercy on me, God, through your grace $)^{74}$

It is plausible that the meditative text on Death at the start of the chapter inspired the reader to write this poem, as it connects closely to the emotional script in the meditative text. ${ }^{75}$ The theme was popular and omnipresent at the time, however, and is, for example, also expounded in the well-known allegorical play of Elckerlijc (Everyman). ${ }^{76}$ Furthermore, two lines of the handwritten poem also occur in a rhymed dialogue between Man and Death, printed in Flanders between 1470 and 1485 as a single leaf, possibly to be hung on a wall. ${ }^{77}$ The stanzas in the copy of the Devout Hours thus seem to be a personal reflection on a familiar theme as much as a consideration on the meditative topic of that day. In any case, the text was deemed a useful addition to Monday's chapter, and its addition was well considered: whoever wrote the poem not only had pen and ink at hand, the verses are neatly written and the writer anticipated the addition of a decorative initial: he left a space open for an initial at the beginning of the text, complete with a 'lettre d'attente.

${ }^{74}$ Amsterdam, UB, Inc. 421, fol. d1 ${ }^{\mathrm{r}}$.

75 The reader has to consider the journey on which he is about to depart, the fact that death will surely come but unannounced as a thief in the night, etc. Interestingly, the meditative texts also contain passages set in verse. See Dlabačová, 'Religious Practice and Experimental Book Production'.

${ }^{76}$ Most recently on this theme in play and painting: Warnar, 'Elckerlijc in beeld'.

${ }^{77}$ Bax, 'Een onbekend gedicht over de dood als schaakspeler'. 
The poem's author followed the same strategy when adding a prayer in prose for a soul in purgatory right after the prologue and immediately before Monday's 'hours of death'. ${ }^{78}$ This complementary prayer seems to be a reaction to the exposition in the latter text on the separation of the soul from the body, the soul's individual judgement upon which she has to travel immediately to purgatory, hell or heaven, and chiefly the fact that the deceased are soon forgotten, in particular by their friends and next of kin:

Ende aldus werden si dicke ende menichwerven vergheten mit lijf ende ziel die nochtan dicwijl langhe inden vaghevier leyt ende biddet grote ghenade, segghende: Ontfermet, ontfermet onser sonderlinge ghi, onse vrienden ende magen die dat goet ende erf ontfanghen hebbet daer om dat ick nu pijn lide.

(And thus they are often and many a time forgotten with body and soul, which nevertheless often lies in purgatory for a long time and prays for great mercy, saying: Take pity, take pity on me, especially you, our friends and family who have received the goods and estate for which I now suffer pain. ${ }^{79}$

The added prayer was to remind the reader of the obligation to help the souls residing in purgatory, especially those who were close to him during earthly life.

Another variation in verse was added by the same user beneath the woodcuts of the Entry into Jerusalem and the Purification of the temple (Plate VI): a single poem split in half due to the limited space in the lower margins. The verses relate closely to the former woodcut and the adjacent prayer that expounds on Christ's entry on a donkey as an example of his great love for mankind and of his meekness, which is taken as a starting point in the poem:

$\mathrm{O}$ almachtich god, o oetmoedich van zeeden

Die op een ezelinne quamt ghereden

En waert doen ontfanghen met groter eeren

Mer die eere verghinc in bitterheiden

Want ghy hebt om ons doerwoenden u seeden

Och, ghenadich god, wilt my nu doch leeren

Dat ic myn hertelyck mach touweert keeren

Ontfermhertich god, verlicht myn van binnen

opent myn herte, hulpt myn duecht vermeren

${ }^{78}$ Amsterdam, UB, Inc. 421, fol. a6v: 'O eerwardighe heere ende genadighe god, want du een troester der berdroefder herten sijt der ghenre die in dijn gracie stan, soe ontfarmedi over die ziele daer ic arme sonder nu sonderlinghen voer biddende byn. O cristus des levende gods soene... soe verlosse vanden tormenten der pynen ende en laetse niet achter, want sij hevet in di ghehoept'.

${ }^{79}$ Amsterdam, UB, Inc. 421, fol. b2 ${ }^{\mathrm{r}}$. 
aproftelen Dntbint mivä allen banton จer fonoอ befcermt mi ễ maect mi fterc in allen boechoen

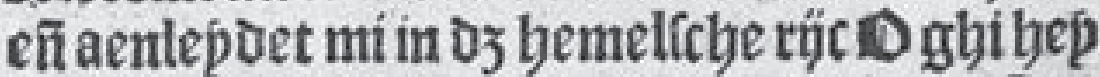
lighe martelaren joet v moz de mín glyegeuẽ ge techte minne warachtighe we de e e puer bette ể een repin leuentenoe verghiffeniffe alle mün re fonden D gloziofe canferfozen goob biot vait mi Dat mi Doervgheghenen wozoe waetoicheit van groeven feoeneñ vollbzenghingbe oer ghes booen on geren D beilige maechoen ubio icts

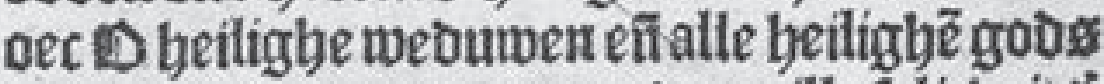
wilt mimerwernen enengoeden wille falicheit ti fielen eñ oe lichaema bzoderlike mine witheit Earcheit vechtuaeroicheiteñ maticheit Een goe oe repune côfciéctie compunctie watachtich berou

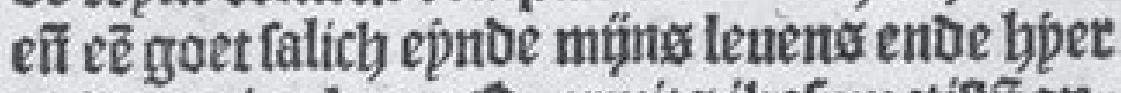
na dat evige leuen iDnermitos ihefumctiftit onfem beer die mittē vadí leeft ende regneert ines nicheịt des heplighen gheeftes van ewen tot ewen $x$ 组

Figure 8. 'Poem on death added on a blank leaf after the end of the chapter for Monday in the only extant copy of Jacob Bellaert's 1486 Haarlem edition', Amsterdam, Universiteitsbibliotheek, Bijzondere Collecties, Inc. 421, fol. $\mathrm{c}^{\mathrm{v}}-\mathrm{d} 1^{\mathrm{r}}$. Reproduced with permission. 
ILLUSTRATED INCUNABULA AS MATERIAL OBJECTS

211

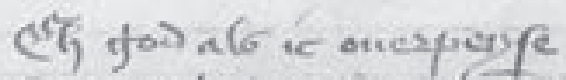
Qic soot-sic min manteringrozt.

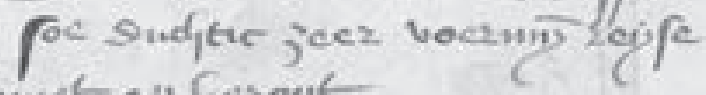
But in Gimer minet op Gerest

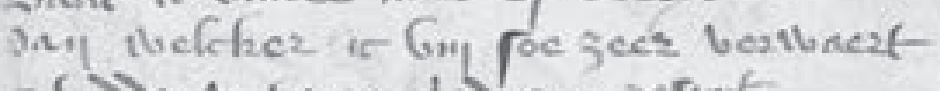

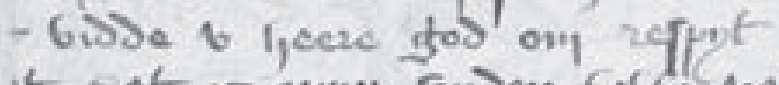

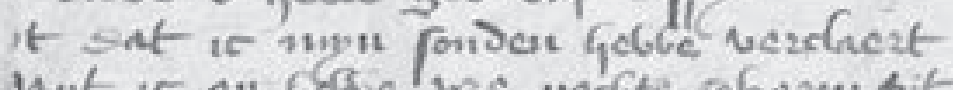

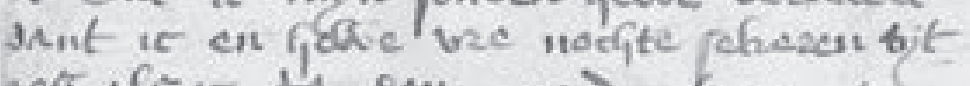

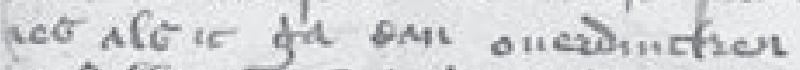
- Gelle di sut \&rote tarment

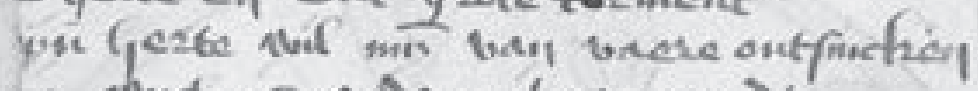
ic surd, $\omega$ cribs nint en candt - Gasar connue osmpotert

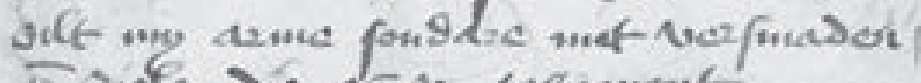
- jide dic da jo taptaminat

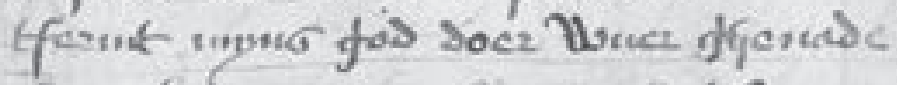
founderye rome afind/fuel, fos

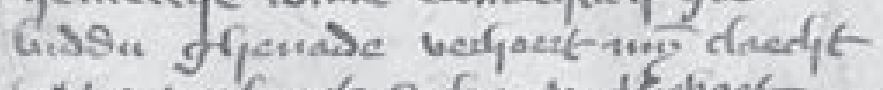

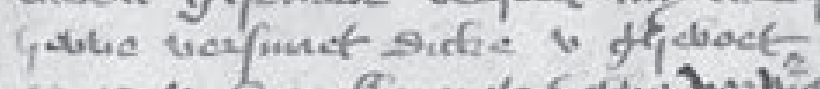

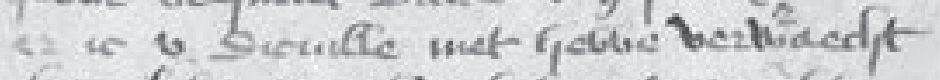

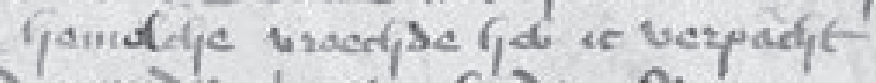
inid murises grocter fonden glowe

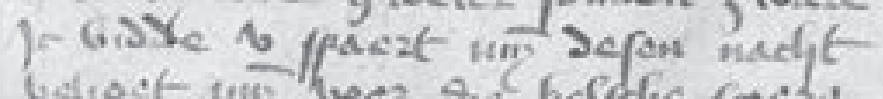

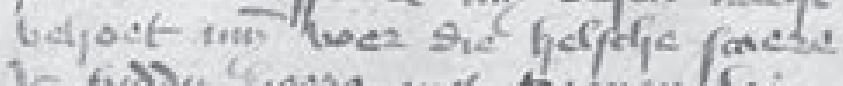

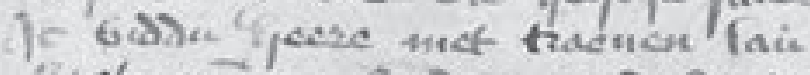

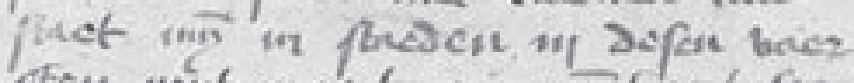

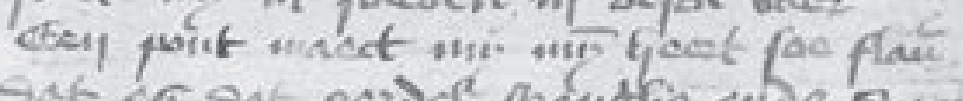

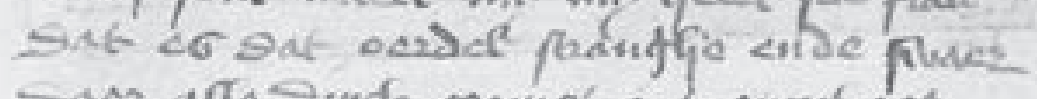

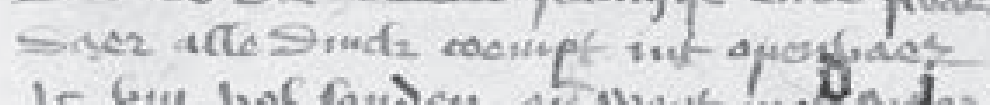

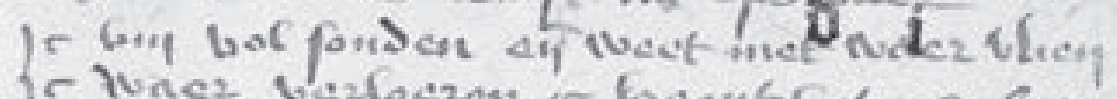

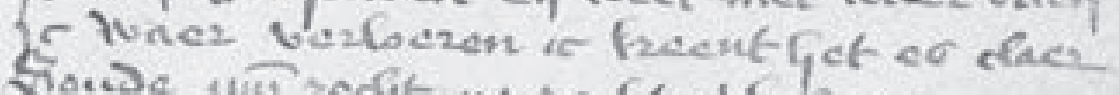
Foude uin reaft ni zeryt bygacy 
Ende zint myn een woncxken van uweer minnen

So dat ic myn zelven mach leeren kinnen.

(Oh God almighty, oh humility of virtues / who came riding on a donkey / and was received with great honours / But the honour turned into bitterness / for you have pierced your virtues with wounds for us / Oh, merciful God, would you still teach me / that I may turn myself wholeheartedly to you / Kind-hearted God, enlighten my inner self / open my heart, help to augment my virtue / And send me a small spark of your love / so that I may learn to know myself. $)^{80}$

This reader-viewer-writer added all three additional texts either at once or within a limited space of time: the ink and probably also the quill used are the same. His handwriting does not correspond with any of the two (sixteenth-century) owner's marks - one in the front and one in the back of the copy - which have been made largely illegible. ${ }^{81}$ We can thus only speculate about his identity. Was he a member of one of the Chambers of Rhetoric? Judging from the literary form of his additions and his fine, professional handwriting in a steady cursive it is fairly certain that he was an educated layman from the upper echelons of society. It is probable that he fulfilled an administrative function within, for example, a town government. Similarly to the owner of the Antwerp copy of Leeu's first edition, he had the means to have the woodcuts richly coloured and rubrication and initials added.

Another (later?) owner with a less sophisticated hand wrote notes of up to four lines in the lower margin beneath numerous woodcuts and prayers in the cycle on salvation history and below the first impression of the woodcut of the Throne of Grace. ${ }^{82}$ Unfortunately his/her elaborations have - together with the colouring of the woodcuts - been washed out and made largely illegible, but even their slumbering existence shows that elaborating further on certain events in salvation history and in the process interweaving text, image, devotion

${ }^{80}$ Amsterdam, UB, Inc. 421 , fols $\mathrm{h} 4^{\mathrm{v}}$ and $\mathrm{h} 5^{\mathrm{v}}$.

81 The copy contains two ownership notices, both of them difficult to decipher, one in the front (fol. a $3^{\mathrm{r}}$ : 'Desen boeck hoert toe / klair (?) van sy..y.. en') and one in the back (fol. $\mathrm{t} 7^{\mathrm{r}}$ : 'desen boeck hoert toe / hert huys van s...').

${ }^{82}$ Erased notes appear in the lower margin of fols b5 ${ }^{\mathrm{v}}$ (Throne of Grace), $\mathrm{b} 6^{\mathrm{v}}-7^{\mathrm{r}}$ (Creation of Eve and adjacent prayer), e $2^{\mathrm{v}}-3^{\mathrm{r}}$ (Annunciation and adjacent prayer), e $3^{\mathrm{v}}$ (Visitation), e $4^{\mathrm{v}}$ (Nativity), e $5^{\mathrm{v}}$ (Circumcision), e $6^{\mathrm{v}}$ (Adoration of the Magi), e $7^{\mathrm{v}}$ (Presentation at the temple), e $8^{v}$ (Flight to Egypt), f1 ${ }^{v}$ (Massacre of the Innocents), g5v (Baptism of Christ), g6v (Temptation

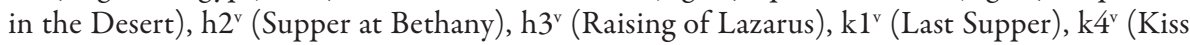
of Judas), $4^{\mathrm{v}}$ (Pilate washing his hands - also contains handwritten note above Pilate: 'rex Assuerus'), $\mathrm{n}^{\mathrm{v}}$ (Carrying of the Cross), $\mathrm{p} 4^{\mathrm{v}}$ (Longinus piercing Christ's side). 
and creativity, practicing one's literary skill in the context of personal piety, was a current practice in handling illustrated incunabula. Other additions have been inserted by different hands, serving the piety of various readers and subsequent owners: couplets of Ave pulcherrima regina, a devotional song relatively popular in the Low Countries, were written on a blank leaf after the end of the penitential psalm for Thursday. ${ }^{83} \mathrm{~A}$ sixteenth-century user from a German-speaking region wrote a prayer on the blank leaf after the penitential psalm for Saturday. ${ }^{84}$

In one of the last woodcuts in the book we find a beautiful example of merging text and image, of mechanical reproduction and handmade addition, and of a reader-viewer actively shaping the meaning and function of the image. The white space in the image of Christ in the wine press has been very effectively used for a dictum through which Christ asks the reader to always be mindful of His Passion: 'O cristiane sis cotidie memor passionis nostre - pater noster ave maria' ( $\mathrm{Oh}$ Christian [believer], be always mindful of our passion) (Fig. 9). ${ }^{85}$ Through the addition of these words the reader-viewer transformed the oblong block of wood pressing down on Christ into a banderol through which the Saviour addresses the reader directly. ${ }^{86}$ While the major part of the adjacent prayer consists of the devotee's speech to the suffering Christ, the perspective is reversed in the prayer's 'prologue' in which Christ speaks to the reader: 'Ic heb die perse alleen ghetreden' (I have trodden the press alone). The handmade addition fits wonderfully with the first paragraph of the prayer and pulls the reader mentally into the image and the event around which the prayer evolves.

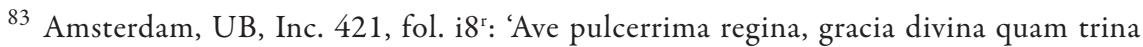
beavit...Vale Hester per te Judeum salvat Mardacheum Rex regnum comprendit Amon suspendit ...[faded]'. The notation contains stanzas 1-3, 10 and 7 in the edition by Mertens and Van der Poel, Het liederenhandschrift Berlijn 190, pp. 281-85. On Ave pulcherrima regina see De Loos, Patronen ontrafeld, pp. 202-03 and the literature mentioned there. The couplets are followed by four short, contemplations (poems?) in Dutch, written with different ink and faded.

${ }^{84}$ Amsterdam, UB, Inc. 421, fol. p2 $2^{\mathrm{r}}$ : 'Lob matter[?] die tallenheyt[?]. Lob cristi gattigkeyt der reyniget siben misse thod diurch die formlich gnad....

${ }^{85}$ Amsterdam, UB, Inc. 421, fol. $\mathrm{s} 8$ ( ('ave maria' has been added by a different hand).

${ }^{86}$ On inscriptions in prints and similar cases see Schmidt, 'Beschrieben, bemalt, zerschnitten', Areford, 'The Image in the Viewer's Hands', pp. 9-13 and Areford, The Viewer and the Printed Image, pp. 69-75. Empty banderoles that could be filled with text by viewers were frequent in prints. 


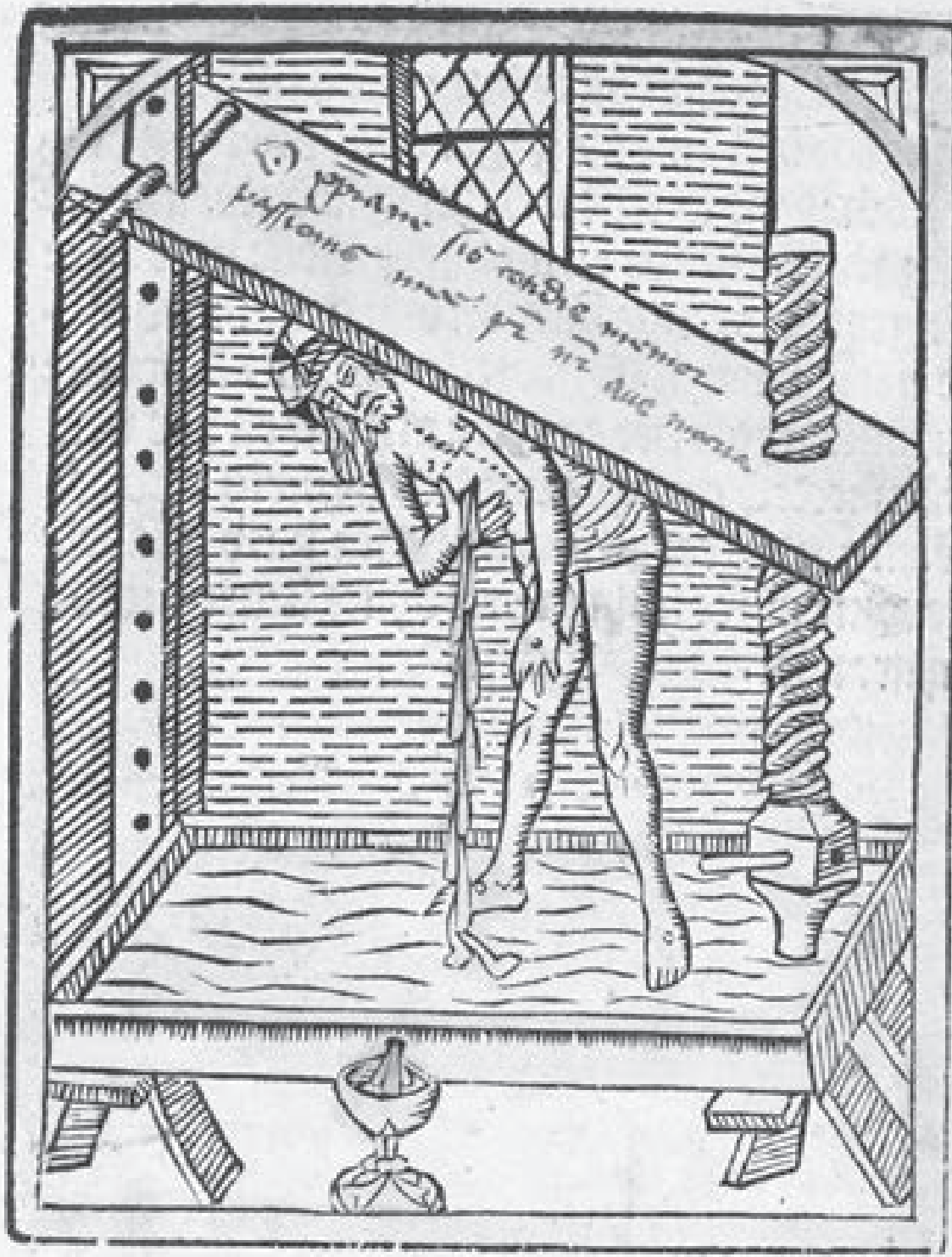

Figure 9. 'The wine press turned into a banderol through which Christ addresses the reader-viewer', Amsterdam, Universiteitsbibliotheek, Bijzondere Collecties, Inc. 421, fols s $8^{v}-\mathrm{t} 1^{\mathrm{r}}$. Copy of Jacob Bellaert's 1486 edition. Reproduced with permission. 
W. Eneboie perfe allez ghetreose queect ope

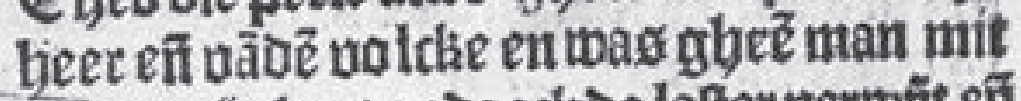

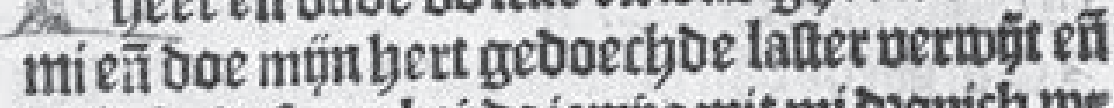
ôfalichejt. fo verbejoe ic mpe mit miboonich we fen foude eñ daer en waøniemät efi wie mi troel

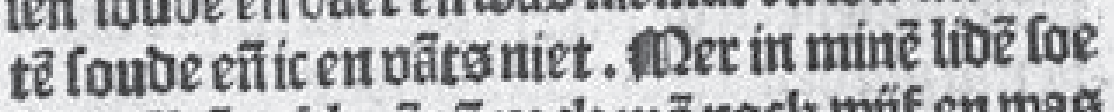

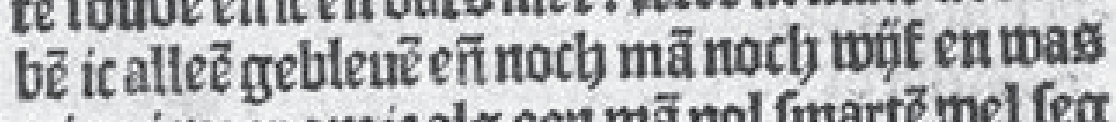
mit mi waer omic aløe een mä nol fmartẻ wel feg

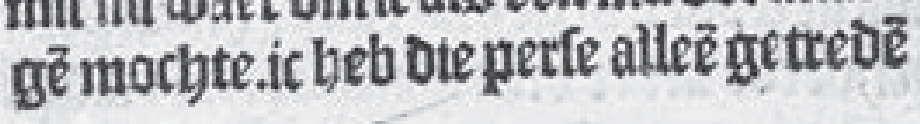

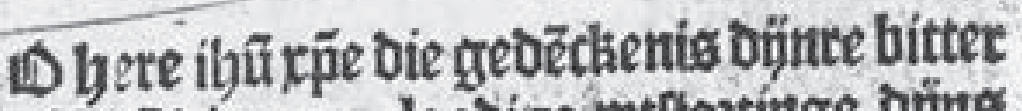
re paltie ent Die ouetulaedige wtitozinge ountro

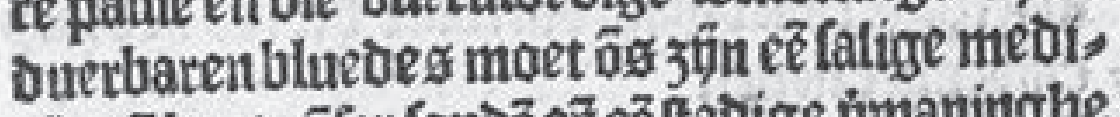

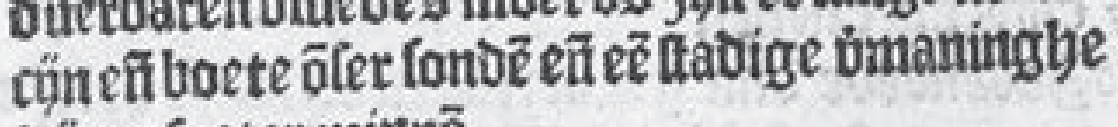
oughure foeter minnẽ

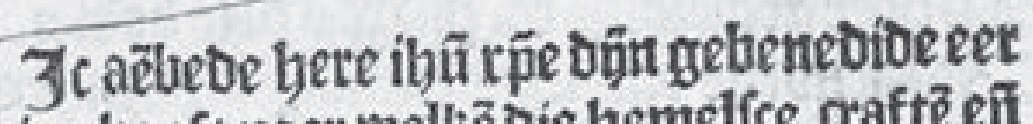
famige hoeft uoer wellie doie hemelice rtaftẽe ei alle ểgelfche gheeftē beuē gectoêt mit Doomen

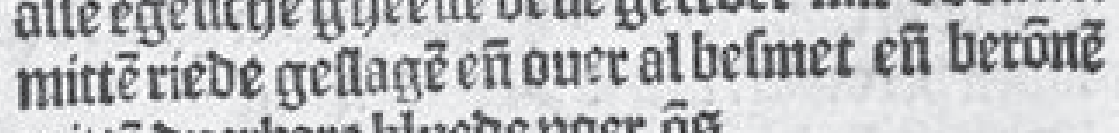
mittê Durtbare blueơ voer â̊

Jc aenbede dat ouettfe vä oinē hrepligẽ hoefoe Dat mitter pekelingben der ffberper ooernen 


\section{Conclusions}

At first sight, the Devout Hours might be taken as just one of the many vernacular religious texts printed in the Low Countries, lacking a distinct character and easily swallowed by what seems to be a grey mass of similar texts. The sheer volume of these works has hitherto prevented in-depth research and their very existence is still too often explained with an oversimplified reference to the Modern Devotion. ${ }^{87}$ The case study shows, however, that the Devout Hours are in fact an innovative product that offered lay people new ways to engage in their spiritual growth. It shows the richness of this material for research into developments in religious literature and the use of text and image in (private) piety.

The approach proposed in this essay emphasizes the hybrid and multimedia character of these books and seeks to interpret their materiality as layers of reception. Thus, the extant copies point to a variety of devout settings in which the book was given meaning: by devout women with a particular predilection for the Holy Virgin (copy of Claes Leeu's edition), by well-educated laymen in urban settings who added their preferred prayers (also in Latin) and original, personal variations that show how profoundly they interacted with the printed texts and images. At least one of the copies of Gerard Leeu's first edition printed in Gouda in 1483 soon found its way to West Flanders, possibly to the town of Bruges. Some handmade additions also show the readers' concern for an up-to-date text - e.g. the addition of verses to the Adoro Te prayer in the copy of Claes Leeu's edition simultaneously indicating that these books were actively used in lay devotion over a relatively long period of time and thus had a profound impact on lay religiosity. The conclusions we can draw about the readership of the text are in keeping with the indications provided by the text itself: there are no signs that any of the copies were kept in religious communities, and both men and women engaged with the books.

The colouring of woodcuts is a frequent yet previously little studied addition. While colouring in religious works might be considered embellishment only - as opposed to colouring in 'scientific works' where it is thought vital for the transmission of technical knowledge - , the colouring in incunabula of a religious nature can also be crucial to the image's (symbolic, iconographic) meaning, its expressive power and its cognitive function. ${ }^{88}$ The figurative contemplation

${ }^{87}$ Pleij, 'The Printing Press as a Long-Term Revolution', p. 290. Van Oostrom, Wereld in woorden, p. 495.

${ }^{88}$ On the meaning of colour in 'scientific' texts see McKitterick, Print, Manuscript and the Search for Order, pp. 79-80: 'While colour was an embellishment for many books, for others, and especially those in the sciences, it was a vital part of the author's and artist's meaning, and its absence in such books often remains an enigma'. 
evoked by the meditative texts and prayers is assisted by the pictorial images that function as meditative tools. This function is enhanced through colour and sometimes by writing onto the image. Apart from making the image livelier and/or its iconography clearer, colour and textual additions can strengthen the relationship between text and image, as we have seen in cases such as Christ before Herod. Even simple forms of colouring can be very effective, such as the yellow shade applied to Mary clothed in the sun in the copy of Claes Leeu's edition. Colouring and other forms of alteration of images in incunabula also show that the way reader-viewers engaged with these images was less distant than in other media and in this sense similar to single-leaf prints - large-scale reproduction, increased accessibility and a more interactive handling of images went hand in hand. ${ }^{89}$ Colouring conventions in (Netherlandish) incunabula need to be studied further, not only as an integral part of the images - as has been increasingly acknowledged for prints -, but also in relation to other media. Gathering data on colouring can tell us how many copies were actually coloured, keeping in mind that only a fraction has survived and that the presence of colour might have influenced (positively or negatively) their survival rate. Eventually, it might become possible to locate copies through colouring techniques, as can be done with the help of other forms of decoration, such as painted borders and pen flourishes.

For now I hope to have shown that the study of individual copies of illustrated incunabula as material traces of a multifaceted interplay between printers, religious developments, and devotional, reading and viewing practices does permit a diversified view of these books and the ways they were deployed in — and thus influenced - the readers' personal piety. Ready made books were customized (sometimes in a continuous process over decades) according to personal preferences, which resulted in a devotional personalisation. The process shows an active and reciprocal interaction between the individual and the printed book: while the book encouraged readers to deepen their individual spirituality through an interiorization of both the textual and visual material, users took this individualisation a step further by projecting their own, personal associations and reflections onto the materiality of the book. While deducing data about owners, readers and their interactions with text and image from (circumstantial) material evidence is a labour-intensive and precarious undertaking, it does provide the best - and effectively only - chance of truly gaining insight into the reception and importance of these works, and thus into the impact they had on private piety and visual culture.

${ }^{89}$ Schmidt, 'Beschrieben, bemalt, zerschnitten', p. 262. 


\section{Works Cited}

\section{Manuscripts and Incunabula}

Amsterdam, Universiteitsbibliotheek, Inc. 421. Devote ghetiden vanden leven ende passie Jesu Christi (Haarlem: Jacob Bellaert, 8 April-20 August 1486, $8^{\circ}$ )

Antwerpen, Ruusbroecgenootschap, L.P. 20/m1099E4. Devote ghetiden vanden leven ende passie Jesu Christi ([Gouda]: Gerard Leeu, 1483, before 10 December, $8^{\circ}$ )

- , MS 202

Cambridge, University Library, Inc.5.E.3.10[2890]. Devote ghetiden vanden leven ende passie Jesu Christi (Gouda: Collaciebroeders, 3 October 1496, $8^{\circ}$ )

Den Haag, Koninklijke Bibliotheek, 150 E 3. Devote ghetiden vanden leven ende passie Jesu Christi (Gouda: Collaciebroeders, 3 October 1496, $8^{\circ}$ )

-169 G 94. Tafel des kersteliken levens. Add: Antonius de Rovere: Lof van den heiligen sacrament (Gouda: Gerard Leeu, 20 August 1478, $4^{\circ}$ )

- , MS 129 G 8

- MS 135 E 19

- MS BPH 79

Leiden, Universiteitsbibliotheek, 1498 F 1 . Devote ghetiden vanden leven ende passie Jesu Christi (Antwerpen: Gerard Leeu, between 18 September 1484 and 9 July 1485, $8^{\circ}$ )

London, British Library, IA.49933. Devote ghetiden vanden leven ende passie Jesu Christi (Antwerpen: Claes Leeu, 29 November 1487, $8^{\circ}$ )

$\longrightarrow$, MS Add. 20729

Princeton, University Library, MS Garrett 63

San Marino, Huntington Library, 100989. Devote ghetiden vanden leven ende passie Jesu Christi (Gouda: Gerard Leeu, 1483, before 10 December, $8^{\circ}$ )

\section{Primary Sources}

Simon van Venlo, Boexken van der officien ofte dienst der missen, ed. by Ludo Simons, with introductory articles by Jos Andriessen, Elly Cockx-Indestege, and Hendrik D. L. Vervliet, 2 vols (Antwerpen: De Schutter, 1982)

\section{Secondary Sources}

Areford, David S., 'Introduction', Studies in Iconography, 4 (2003), 1-4

—, 'The Image in the Viewer's Hands: The Reception of Early Prints in Europe', Studies in Iconography, 4 (2003), 5-42

- The Viewer and the Printed Image in Late Medieval Europe (Farnham: Ashgate, 2010)

Bax, D., 'Een onbekend gedicht over de dood als schaakspeler', Tijdschrift voor Nederlandse Taal-en Letterkunde, 68 (1951), 241-44 
Blume, Clemens, and Guido M. Dreves eds, Analecta Hymnica Medii Aevi, vol. 33 (Leipzig: Reisland, 1898)

Bogaart, Saskia, Geleerde kennis in de volkstaal. 'Van den proprieteyten der dinghen' (Haarlem 1485) in perspectief (Hilversum: Verloren, 2004)

Brinkman, Herman, 'De Const ter perse. Publiceren bij de rederijkers voor de Reformatie', in Geschreven en gedrukt. Boekproductie van handschrift naar druk in de overgang van Middeleeuwen naar moderne tijd, ed. by Herman Pleij, Joris Reynaert and others (Gent: Academia Press, 2004), pp. 157-75

Chartier, Roger, 'Afterword: Materiality and Meaning', Word \& Image, 17 (2001), 181-83

Conway, William Martin, The Woodcutters of the Netherlands in the Fifteenth Century, 3 vols (Cambridge: Cambridge University Press, 1884)

Dackerman, Susan, 'Introduction', in Painted Prints: The Revelation of Color in Northern Renaissance \& Baroque Engravings, Etchings \& Woodcuts, ed. by Susan Dackerman (Baltimore: The Baltimore Museum of Art, 2002), pp. 1-6

— , 'Painted Prints in Germany and the Netherlands', in Painted Prints: The Revelation of Color in Northern Renaissance \& Baroque Engravings, Etchings \& Woodcuts, ed. by Susan Dackerman (Baltimore: The Baltimore Museum of Art, 2002), pp. 9-47

Dackerman, Susan, ed., Painted Prints: The Revelation of Color in Northern Renaissance \& Baroque Engravings, Etchings \& Woodcuts (Baltimore: The Baltimore Museum of Art, 2002)

Delft, Marieke van, 'Illustrations in Early Printed Books and Manuscript Illumination: The Case of a Dutch Book of Hours printed by Wolfgang Hopyl in Paris in 1500', in Books in Transition at the Time of Philip the Fair: Manuscripts and Printed Books in the Late Fifteenth and Early Sixteenth Century Low Countries, ed. by Hanno Wijsman (Turnhout: Brepols, 2010), pp. 131-64

De vijfhonderdste verjaring van de boekdrukkunst in de Nederlanden (Brussel: Koninklijke Bibliotheek Albert I, 1973)

Dewitte, Alfons, 'Het Brugse St.-Jans en St.-Lucasgilde der librariers 1457, 1469', Biekorf, 96 (1996), 334-40

Dlabačová, Anna, 'Chatten met Scriptura. Het leven van Jezus in een Antwerpse bestseller', Boekenwereld, 33 (2017), 25-29

—, 'Drukken en publieksgroepen. Productie en receptie van gedrukte Middelnederlandse meditatieve Levens van Jezus (ca. 1479-1540)', Ons Geestelijk Erf, 79 (2008), 321-68

_- Literatuur en observantie. De 'Spieghel der volcomenheit' van Hendrik Herp en de dynamiek van laatmiddeleeuwse tekstverspreiding (Hilversum: Verloren, 2014)

_- 'Religious Practice and Experimental Book Production. Text and Image in an Alternative Layman's "Book of Hours” in Print and Manuscript', Journal of Historians of Netherlandish Art, 9.2 (2017), DOI: 10.5092/jhna.2017.9.2.2

Dlabačová, Anna, and Daniëlle Prochowski, 'Preken en publiceren. De franciscaanse observantie als producent en aanjager van religieuze literatuur in de Lage Landen, circa 1490-1560. Ter inleiding', Ons Geestelijk Erf, 85 (2014), 225-29

Gnirrep, Kees, 'Relaties van Leeu met andere drukkers en met boekverkopers', in Een drukker zoekt publiek. Gheraert Leeu te Gouda 1477-1484, ed. by Koen Goudriaan and others (Delft: Eburon, 1993), pp. 193-203 
Goedings, Truusje, 'Afsetters en meester-afsetters'. De kunst van het kleuren 1480-1720 (Nijmegen: Vantilt, 2015)

Goudriaan, Koen, 'Apostolate and Printing: The Collaciebroeders of Gouda and their Press', in Between Lay Piety and Academic Theology: Studies Presented to Christoph Burger on the Occasion of his $65^{\text {th }}$ Birthday, ed. by Ulrike Hascher-Burger, August den Hollander and Wim Janse (Leiden: Brill, 2010), pp. 433-52

Goudriaan, K., and G. A. M. Willems, eds, Gheraert Leeu, meesterprenter ter Goude, 1477-1484 (Gouda: Stedelijk Museum Het Catharina Gasthuis, 1992)

Goudriaan, Koen, and others, eds, Een drukker zoekt publiek. Gheraert Leeu te Gouda (Delft: Eburon, 1993)

Hellinga, Lotte, 'Gheraert Leeu, Claes Leeu, Jacob Bellaert, Peter van Os van Breda', in De vijfhonderdste verjaring van de boekdrukkunst in de Nederlanden (Brussel: Koninklijke Bibliotheek Albert I, 1973), pp. 283-91

Hellinga, Wytze, and Lotte Hellinga, The Fifteenth-Century Printing Types of the Low Countries, vol. I (Amsterdam: Menno Hertzberger, 1966)

Hindman, Sandra, Pen to Press: Illustrated Manuscripts and Printed Books in the First Century of Printing (College Park: Art Dept., University of Maryland, 1977)

Jecmen, Gregory, 'Color Printing and Tonal Etching: Innovative Techniques in the Imperial City, 1487-1536', in Imperial Augsburg: Renaissance Prints and Drawings, 1475-1540, ed. by Gregory Jecmen and Freyda Spira (Washington, DC: National Gallery of Art, 2012), pp. 67-101

Kok, Ina, 'A Rediscovered Devote ghetiden with Interesting Woodcuts (CA 1117)', Quaerendo, 13 (1983), 167-90

- Woodcuts in Incunabula Printed in the Low Countries, 4 vols (Houten: Hes \& De Graaf, 2013)

Larkin, Graham, and Lisa Pon, 'Introduction: The Materiality of Printed Words and Images', Word \& Image, 17 (2001), 1-6

Loos, Ike de, Patronen ontrafeld. Studies over Gregoriaanse gezangen en Middelnederlandse liederen (Hilversum: Verloren, 2012)

McKitterick, David, Print, Manuscript and the Search for Order, 1450-1830 (Cambridge: Cambridge University Press, 2003)

—_, 'Tanned Calf over Wooden Boards, Early Sixteenth Century', Online exhibition The Use and Abuse of Books: Private Lives of Print (Cambridge: Cambridge University Library), https://exhibitions.lib.cam.ac.uk/incunabula/artifacts/tanned-calf-earlysixteenth-century/ [accessed 10 April 2017]

Mertens, Thom, Poel, Dieuwke van der, and others, Het liederenhandschrift Berlijn 190. Hs. Staatsbibliothek zu Berlin - Preußischer kulturbesitz, germ. oct. 190 (Hilversum: Verloren, 2013)

Mone, F. J., Hymni Latini Medii Aevi, vol. 2 (Freiburg im Breisgau: Herder, 1854)

Moolenbroek, Jaap van, “'Dat liden ende die passie ons Heren Jhesu Cristi”. Een bestseller uit het fonds van Gheraert Leeu in vijftiende-eeuwse context', in Een drukker zoekt publiek. Gheraert Leeu te Gouda 1477-1484, ed. by Koen Goudriaan and others (Delft: Eburon, 1993), pp. 81-110 
Oltrogge, Doris, 'Illuminating the Print: The Use of Color in Fifteenth-Century Prints and Book Illumination', in The Woodcut in Fifteenth-Century Europe, ed. by Peter Parshall (Washington, DC: National Gallery of Art, 2009), pp. 298-315

Oostrom, Frits van, Wereld in woorden. Geschiedenis van de Nederlandse literatuur 1300-1400 (Amsterdam: Bert Bakker, 2013)

Parshall, Peter, 'Prints as Objects of Consumption in Early Modern Europe', Journal of Medieval and Early Modern Studies, 28 (1998), 19-36

Pleij, Herman, 'The Printing Press as a Long-Term Revolution', in Books in Transition at the Time of Philip the Fair: Manuscripts and Printed Books in the Late Fifteenth and Early Sixteenth Century Low Countries, ed. by Hanno Wijsman (Turnhout: Brepols, 2010), pp. 287-307

Primeau, Thomas, 'Coloring Within the Lines: The Use of Stencil in Early Woodcuts', Art in Print, 3.3 (2013), http://artinprint.org/article/coloring-within-the-lines-the-useof-stencil-in-early-woodcuts/ [accessed 10 April 2017]

_-, 'The Materials and Technology of Renaissance and Baroque Hand-Colored Prints', in Painted Prints: The Revelation of Color in Northern Renaissance \& Baroque Engravings, Etchings \& Woodcuts, ed. by Susan Dackerman (Baltimore: The Baltimore Museum of Art, 2002), pp. 49-78

Renaud, Adam, 'The Emergence of Antwerp as a Printing Centre: From the Earliest Days of Printing to the Reformation (1481-1520)', De gulden passer. Tijdschrift voor boekwetenschap, 92 (2014), pp. 11-28

Reypens, L., 'Belang der "Devote ghetiden” voor de geschiedenis der lekenspiritualiteit', Ons Geestelijk Erf, 33 (1959), 406-12

_ - 'Een onbekend vijftiendeeuws handschrift met een Westvlaamse vertaling van het tweede boek der Imitatie', Ons Geestelijk Erf, 32 (1958), 428-31

— - 'Rond een Antwerpse druk der "Devote ghetiden". Het enige bekende exemplaar weer thuisgewezen en een tweede ontdekt', Ons Geestelijk Erf, 33 (1959), 100-06

Rosier, Bart, 'Gheraert Leeus illustraties bij het leven van Jezus', in Een drukker zoekt publiek. Gheraert Leeu te Gouda 1477-1484, ed. by Koen Goudriaan and others (Delft: Eburon, 1993), pp. 133-61

Schmidt, Peter, 'Beschrieben, bemalt, zerschnitten. Tegernseer Mönche interpretieren einen Holzschnitt', in Einblattdrucke des 15. und frühen 16. Jahrhunderts: Probleme, Perspektiven, Fallstudien, ed. by Volker Honemann, Sabine Griese, Falk Eisermann and Marcus Ostermann (Tübingen: Max Niemeyer, 2000), pp. 245-76

Stock, J. van der, Printing Images in Antwerp: The Introduction of Printmaking in a City, Fifteenth Century to 1585 (Rotterdam: Sound \& Vision Interactive, 1998)

Thienen, G. van, and J. Goldfinch, Incunabula Printed in the Low Countries: A Census, Bibliotheca bibliographica Neerlandica, 36 (Nieuwkoop: De Graaf, 1999)

Warnar, Geert, 'Elckerlijc in beeld. Jan Provoosts "Rijkaard en de dood", Spiegel der Letteren, 57 (2015), 273-89

Wilson, Adrian, assisted by Joyce Lancaster Wilson, Making of the Nuremberg Chronicle (Amsterdam: Nico Israel, 1976) 
